\title{
ACTIONS IN TIME: AFTER THE BREAKAGE OF POTTERY AND BEFORE THE CONSTRUCTION OF WALLS AT THE SITE OF CASTELO VELHO DE FREIXO DE NUMÃO
}

\author{
LESLEY K. MCFADYEN ${ }^{(1)}$
}

Abstract:

\begin{abstract}
This article is about an enclosure that would normally be defined by its walls. There are many other sites like this in the Iberian Peninsula. Traditional accounts would interpret this site as a fortified settlement, although the excavation director Susana Oliveira Jorge has written in more ritual terms of a monumentalised hill. However, there is another issue, and it underlies and forges the construction of both of these accounts, they are constituted through the spatial. The spatial distributions of 'architectural' and 'material culture' elements are key to these understandings. But what of their temporal dimensions?

The enclosing walls of Castelo Velho are a complicated maze of different construction projects that rarely crystallise into clear static forms, and appear to be as much material practice as architecture. Fragments of pottery, as well as slabs of stone, make up these entwined structures and because of this I used the pottery to get at space in a different way. In particular, I have utilised the temporal qualities inherent in assemblages of potsherds in order to understand the temporality of the entanglement of walls. Pots, like walls, are not frozen objects but have extended histories and if you locate these alongside the extended histories of buildings you get an overlap. It is this overlap that adds an extra temporal complexity that enhances the understanding of the site.

In this article, I consider the significance of this temporal trajectory, and how it reconfigures accounts of the making and unmaking of space in the Chalcolithic.
\end{abstract}

Keywords: time, fragmentation, pottery, architecture, practice, history

Resumo:

\begin{abstract}
Acções no Tempo: depois da fragmentação da cerâmica e antes da construção de estruturas em Castelo Velho de Freixo de Numão

Este texto centra-se na arquitetura do recinto murado de Castelo Velho de Freixo de Numão (Vila Nova de Foz Côa) datado do III $/ 1^{\mathrm{a}}$ metade do II milénio AC. A arquitetura destes recintos murados é tradicionalmente associada a sistema de fortificação, sendo a sua construção uma resposta à necessidade de defesa de pessoas e bens. Porém, desde meados dos anos 90 do século XX, têm-se multiplicado os pontos de vista sobre este tipo de arquitetura, surgindo novos modos de discutir a sua espacialidade e temporalidade. Com o propósito de contribuir para esta discussão, pretendemos explorar o entrelaçamento entre os "elementos arquitectónicos" e os "elementos de cultura material".

Os muros que definem Castelo Velho são um complicado labirinto de distintos projetos de construção que raramente se cristalizam em formas claras e estáticas. Pelo contrário, sugerem que se ensaie uma ideia de arquitetura como um conjunto de complexas práticas materiais. $\mathrm{O}$ estudo que agora se apresenta partiu da análise cerâmica para tentar compreender a construção do espaço de um modo diferente, pois o entrelaçado de estruturas não é apenas composto por lajes de pedra, mas também por fragmentos de cerâmica. Prestando particular atenção às qualidades temporais de conjuntos de fragmentos cerâmicos específicos, tentaremos compreender a temporalidade do emaranhado das paredes. Os recipientes cerâmicos, tal como as paredes, não são objetos congelados. Estes vestígios materiais apresentam longas histórias que, colocadas ao lado das histórias de construção, oferecem um conjunto de sobreposições de acontecimentos. São estas sobreposições que, ao adicionar complexidade temporal e espacial ao estudo destes contextos, aumentam as possibilidades de compreensão do recinto.
\end{abstract}

Palavras-chave: tempo; fragmentação; cerâmica; arquitetura; práticas; histórias

Received: 4 May, 2016; Accepted: 15 September, 2016

\section{ARCHITECTURE}

.. architecture is in itself opaque, when considered as a physical expression of spatial organisation' (Susana Oliveira JORGE 1999: 118).

Time and time again in our prehistory, in our accounts of the past, we see the depiction of a plan drawing of a building, and an accompanying text that describes the intentional design of the monument and the significance of its final form. But how can this be? How can a drawing depict a future projection, and a past record, at the same time? Why do these particular drawings bind design and record together? This is to do with how we allow image and object to stand together in our work.

From the beginning of architectural history, the drawing of a line has been bound to the drawing forth of an idea (HILL 2003): the appearance of design. This is knowledge of architecture where it is thought about before it is built, done through drawing, and drawings are then translated into complete buildings. Within this intellectual scenario, architecture is not only made through a conceived idea, it is made only once as a singular entity (ibid). It also suggests that we can read back to

${ }^{(1)}$ Birkbeck, University of London, 1.mcfadyen@bbk.ac.uk 
the intentions of the architect in drawing and building. The source of creativity would seem to be located in image and object, and not in the practice of making. This concept of design in architectural history jumps from an idea to an outcome, but it misses out practice. Conversely, it states that we can find the principle of design by tracing the novelty of its outcomes back to ideas in the mind. Design is innovation, and on these terms it is never formed by thinking-through-practice. Even in the archaeology of architecture, with all of its timedepth, there is no real account of how things are changed, altered or transformed in the process of their making. Of course this information appears in our texts, but it exists as secondary detail, or as an interesting digression. These actions are not seen to be part of the design process itself. Furthermore, in our archaeologies of architecture it would seem that we are supposed to identify a type of building and then describe its use. Crucially, occupation is not described as a part of the architectural process either; it is seen as a practice that comes after a building has been made (HILL 1998).

There is a real legacy from architectural history of an architecture that exists as image and object (EvANs 1996), created by a design process that is understood to move from idea to outcome (HILL 2003). This situation is further complicated in archaeology by the archaeological recording process itself, where the plan drawing is used to demonstrate that there was a clear outcome to a building project, and that the archaeological drawing can take us back to the ideas of those who created architecture in the past. The plan has taken on an iconic status in archaeological accounts as if its graphic detail creates reality at a higher level of realism than the evidence itself.

$\begin{array}{llll}\begin{array}{l}\text { Drawing } \\ \text { (architect) }\end{array} & \begin{array}{l}\text { Building } \\ \text { (structure) }\end{array} & \begin{array}{l}\text { Drawing } \\ \text { (archaeologist) }\end{array} & \begin{array}{l}\text { Building } \\ \text { (idea) }\end{array}\end{array}$

The team that work on the site of Castelo Velho de Freixo de Numão (Vila Nova de Foz Côa) (see Fig. 1) is addressing many of the problems of the paradigm in architecture that I have just identified above. It is being tackled in our refusal to write about evidence as the residue of yet another fortified settlement, and through the alternative concept of the site as a monumentalized hill. This concept was introduced, in part, due to a desire to extend and include other elements in the accounts that we write of architecture, i.e. protruding bedrock and landscape. These have been included because they were not simply elements upon which enclosure walls were built, but instead were an integral part of the making of the built world in prehistory (S.O. JORGE 1994 and 2005). These elements are deliberately being drawn into the design process, but through a process of design that is being described and understood on more inclusive and dynamic terms. The terms are inclusive because they draw more of the evidence from the excavation into the account, and they extend the temporal and spatial range of that which constitutes architecture. Furthermore, the terms operate through a dynamic (through action rather than object), in an attempt to think architecture through the practice of its making.

It was not possible to identify a series of constructions that represent the residues of distinct phases. Perhaps, rather than thinking that the archaeologists that excavated Castelo Velho were unlucky in not being able to uncover ideal stratigraphy, instead the woven nature of these condi-

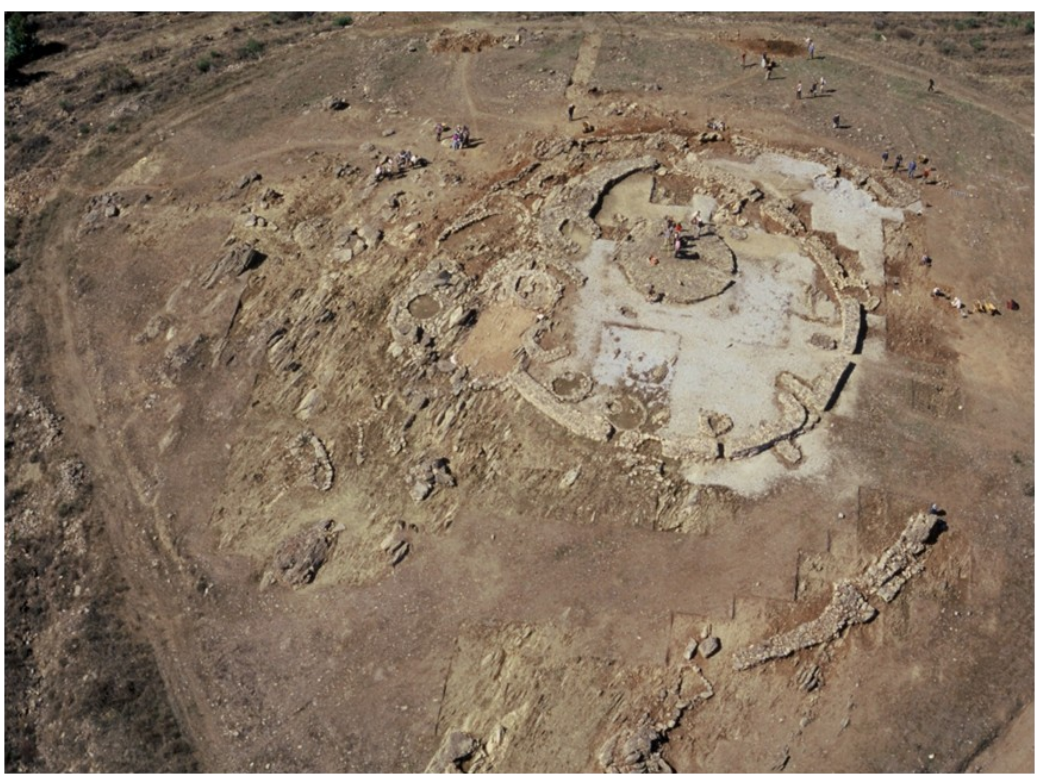

Fig. 1. The site of Castelo Velho de Freixo de Numão (Vila Nova de Foz Côa) (photo by Susana Oliveira Jorge).

Fig. 1. O sítio de Castelo Velho de Freixo de Numão (Vila Nova de Foz Côa) (foto de Susana Oliveira Jorge). 
tions suggest that it was the dynamic of building that was the point, and that the built world was inhabited through its ongoing production. I want to add to this work and suggest that architecture involves dynamics of change and alteration: and it draws design, construction and use into the same equation.

\section{ARCHITECTURE WITHOUT SEQUENCE}

The areas that I have studied in my research of the site of Castelo Velho include: a pit, a structure with human bone, a portion of the ramp and the contexts that it covered, a structure with seeds, and two hearths .

\section{Pit}

Of all of these features, only the structural elements of the pit can be described in any sequential order: a cut shape made into the clay that was then backfilled with soil and sherds (although I will come back to the temporal dimension the potsherds add to that story, later) (see Fig. 2). But at the larger scale of the site, things are not clear with this closed context; this feature is isolated from the other structural elements.

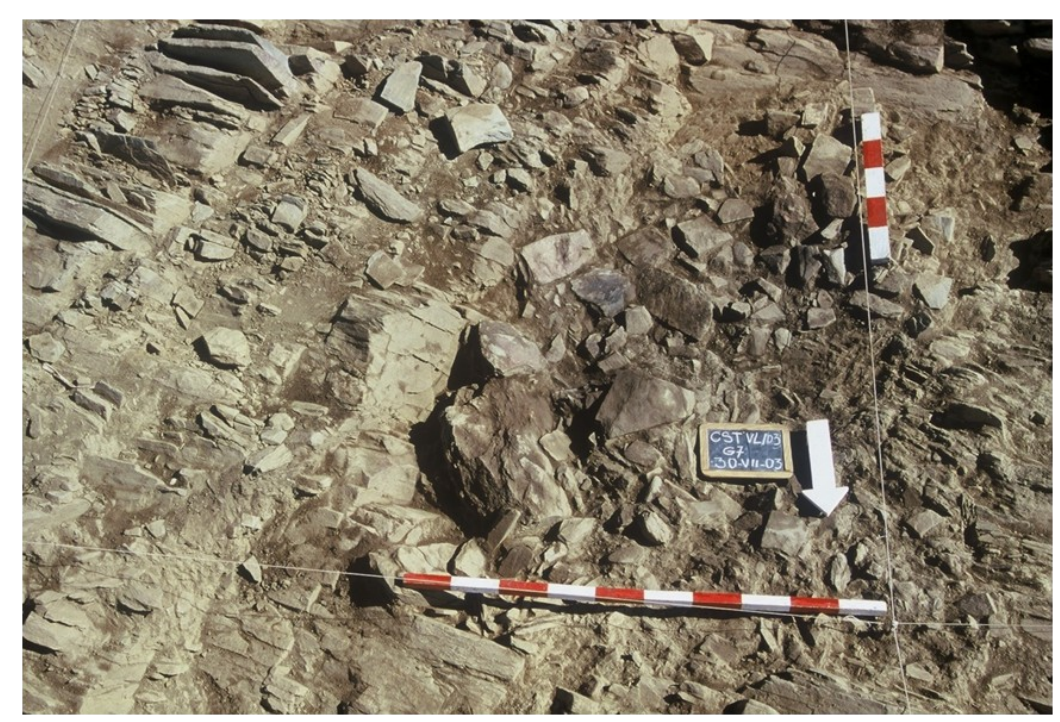

Fig. 2. The pit, located in G7 (photo by Susana Oliveira Jorge).

Fig. 2. A fossa, localizada nas quadrículas G7(foto de Susana Oliveira Jorge).

\section{Structure with Bone}

For the other features, they cannot be picked apart to reveal a clear stratigraphic order. The partly enclosed, partly open, semi-circular structure with human bone was made out of coursed walling in schist and clay (see Fig. 3). The structure also seemed to be partly defined by protruding bedrock on its more open eastern side. Previously, it was suggested that the structure was inserted into the ramp that encircled to the west and south of the main enclosure wall (S.O. JORGE et al. 1998-1999). This would suggest that it was built late. However, the ramp was built from a series of different materials, and using a range of different construction techniques, suggesting it was not constructed as a single piece of architecture. Neither was it built in clear sequential sections, and it appears that it was returned to and modified throughout the history of the site's occupation. This situation has been made more complicated by further excavation. Under a part of the ramp, within Area 6, there was a yellow clay sediment, that had built up within a depression in the bedrock. This had been used as a platform. The excavated quadrants of J13, J14 and I14 were in the vicinity of a structure, but the structure was 'clean' of artefacts, and so the concentrations of material culture that were recovered during the excavation were not bound by any feature (OLIVEIRA 2003: 84). There are similarities between this structure and the structure with bone in that both seem to relate to the protruding bedrock, and these outcrops are used to add to the making and defining of the architecture. Therefore, it is also possible that the structure with bone was constructed early, and that the ramp was then built up around it. What is clear is that it is not possible to build a straightforward sequence from under the ramp, to the ramp, to the structure with bone. Furthermore, the material culture in each of these features is from open (or partly open) contexts.

\section{Structure with Seeds}

In the case of the structure with seeds, the feature was constructed out of coursed walling in schist and clay and the lower part of the feature was held within a pit cut into the clay. The upper part of the north-western edge of the feature continued and widened the line of the main enclosure wall, along its western entrance (i.e. as if the enclo- 


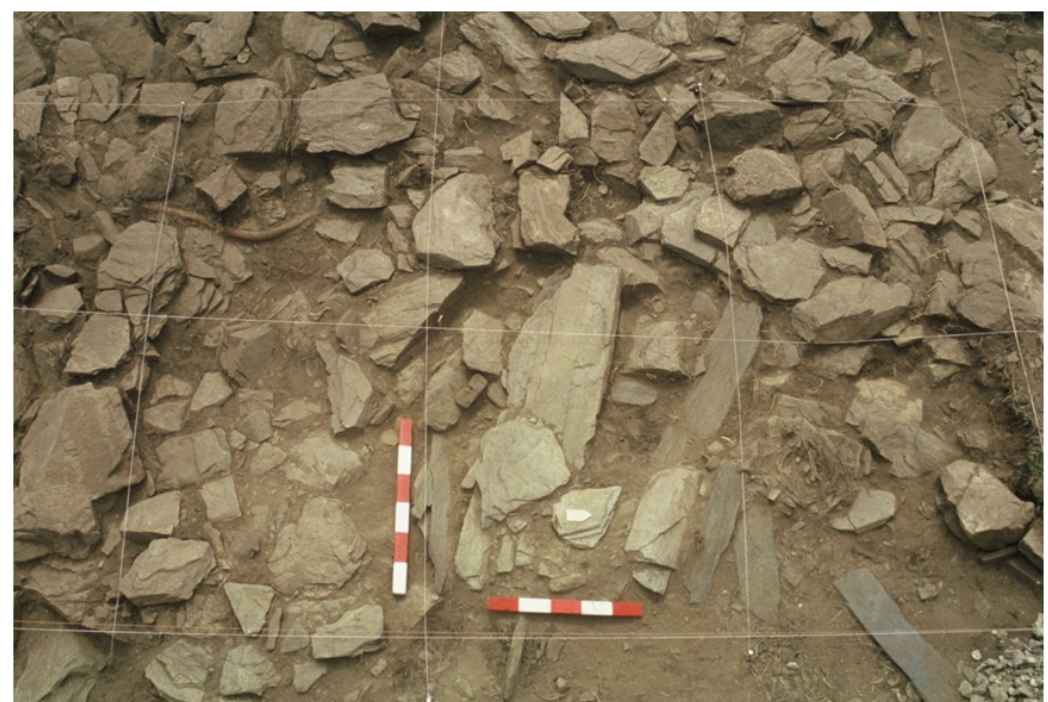

Fig. 3. Structure with human bone, located in I1 1 (photo by Susana Oliveira Jorge).

Fig. 3. Estrutura com ossos humanos, quadrícula I11 (foto de Susana Oliveira Jorge).

sure wall had been built first and then later elaborated through the construction of the structure with seeds). So the entire structure could have been built as the elaboration of the enclosure wall and the entrance-W1 (see Fig. 4). However, a cut into the underlying clay also indicated that the lower part of the seed structure could have been left freestanding for a period of time. The seed structure was identified in 2001, during the dismantling of the enclosure wall, and it was found that there was an earlier line of the wall, and that this had followed another path further to the west. Therefore, the structure with seeds could have been a freestanding feature, or built in tandem with an earlier build of the enclosure wall, and then the upper part built and more formally tied into an ornate enclosure wall project.

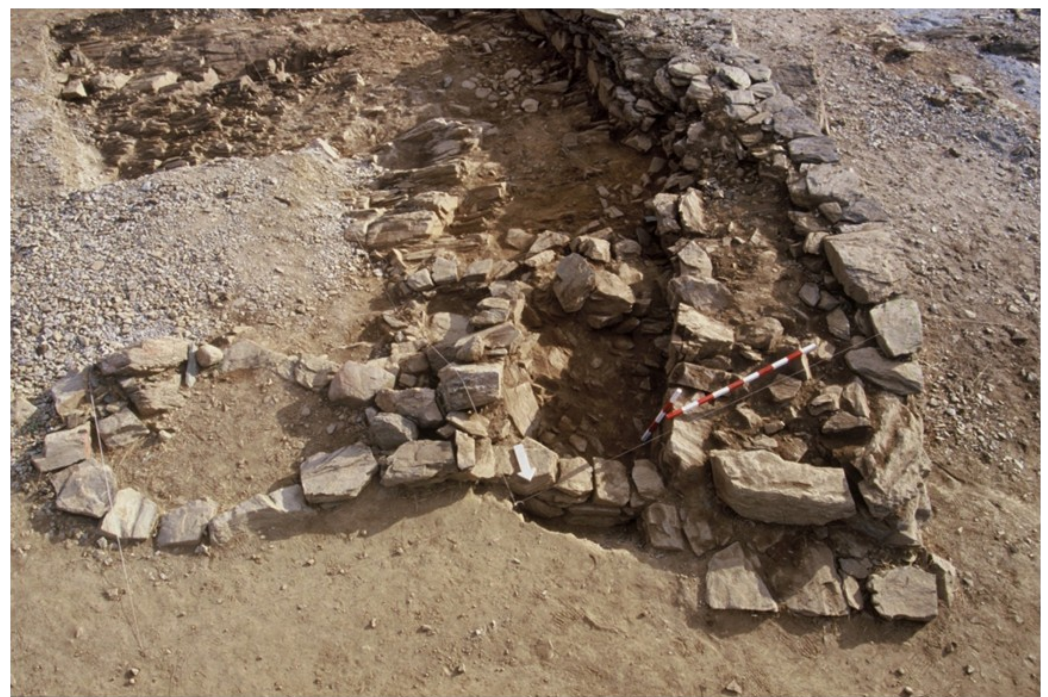

Fig. 4. Structure with seeds, located in E10 (photo by Susana Oliveira Jorge).

Fig. 4. Estrutura com sementes, quadrícula E10 (foto de Susana Oliveira Jorge).

\section{Two Hearths}

The stratigraphy of the two hearths context was similarly complex and also related to the main enclosure wall (see Fig. 5). One of the hearths was located in an interruption of the wall, and the other was inside the area of the enclosure. Firstly, there was a deposit of yellow clay that was devoid of artefactual material (layer 6), and within which was set an alignment of stones that suggested the existence of an older entry to the enclosure wall. The two hearths, and the distribution of material culture, were in a deposit of black clay (4b) from the excavated quadrants $\mathrm{C} 5$ and $\mathrm{C} 6$, and this deposit had built up in the break (entranceway) in the 
enclosure wall identified in layer 6 , and the deposit formed a slope as it went up to the lower level of stones of the actual wall itself. There was a further distribution of material culture with slabs of blue schist and then the blocking of the former entranceway with the construction of an upper level of wall. Oliveira (2003: 108) argues that all the activities in this area were to do with the closure of an entranceway, and the transformation of the enclosure wall architecture. Furthermore, just from the details of the deposit of the black clay (4b), it is possible to see how the enclosure wall did not exist as a singular built object, but was instead a project that was altered and changed through time.

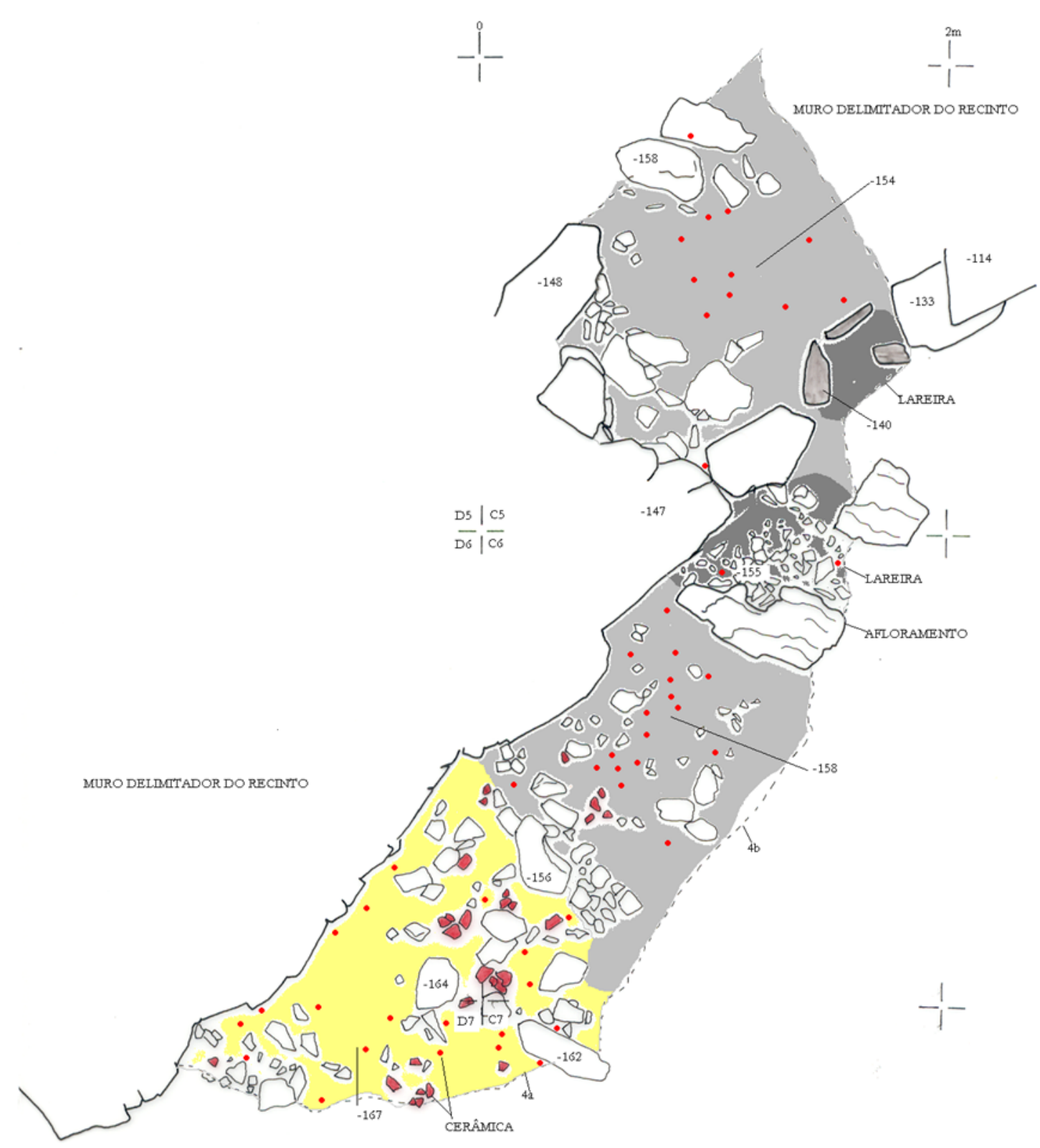

Fig. 5. The two hearths, located in C5/C6/D5/D6 (drawing by Maria de Lurdes Oliveira).

Fig. 5. As duas lareiras, quadrículas C5/C6/D5/D6 (desenho de Maria de Lurdes Oliveira).

\section{Comment}

These four examples demonstrate that the architectural details of the site of Castelo Velho are a complicated maze of different construction projects that rarely crystallise into clear static forms, and they appear to be as much material practice as architecture. Fragments of pottery, as well as slabs of stone, make up these entwined structures and because of this, in my own analysis, I use the pottery to get at space in a different way. In particular, I utilise the temporal qualities inherent in assemblages of potsherds in order to understand the temporality of the entanglement of architectural elements. Pots, like walls, are not frozen objects but 
have extended histories, and if you locate these alongside the extended histories of buildings you get an overlap. It is this overlap that adds an extra temporal complexity that enhances the understanding of the site. However, before I move onto a discussion of my own work I want to mention the implications of some of the previous studies of material culture from the site.

\section{AN INHABITED ARCHITECTURE}

'There is no formula for overcoming these limitations: what is needed is a new mental position on the part of researchers. They must use the largest possible amount of contextualised (and not only archaeo-graphic) 'data'..' (S.O. JORGE 1999: 99).

Of the previous work that has been undertaken on the material culture from Castelo Velho, two studies were temporal in character, and focused on different broad chronological phases of the site's history. One was a study of the Bronze Age pottery (VARELA 2000), and the other was on the material that was recovered from the early contexts and features of the site (OLIVEIRA 2003). Another two studies focused on particular categories of material culture, the Cogeces pottery (PEREIRA 1999), and the loom weights (GOMES 2003). The analysis that was undertaken by Baptista (2003) was spatial in character, and was concerned with the pottery that was inside the main enclosure wall.

In each of these pieces of research, the authors have carried out a morphological and technical characterization of the material culture in order to produce typologies of pottery and lithics. However, each had a different approach and goal. With the Cogeces pottery, the analysis was conducted at the level of the site, and then this was extended out to consider a much wider regional context (PEREIRA 1999). There was a group of studies that privileged the role of material culture at the site-level, and these included attempts to focus in on smaller scale details in order to define functional areas (CRUZ 1993, Botelho 1996, Silva 1996, CARDOSO 1996, VARELA 2000, and GOMES 2003: 87-102). Another group took a contextual approach and tried to problematize the different scenarios in which the material culture was being used (BAPTISTA 2003, GOMES 2003: 120-137, OLIVEIRA 2003). In these later contextual studies, the authors highlighted the concept of deposition in their interpretations. The impact of these works was that construction and occupation were linked more closely through the study of material culture. This is important.

It is the last group (BAPTISTA 2003, GOMES 2003, OLIVEIRA 2003) that works in parallel with my own archaeology and that I want to focus on. The approach is a contextual one, and this means that the researchers studied all of the items of material culture, and the ways in which they were physically associated together at particular points of the site i.e. the assemblage of artefacts and how these were associated together in or with the details of the excavated context. This is an analysis of the depositional contexts that were identified through the process of excavation, knowledge of the physical relationships between things, and so it is spatial in its focus. But there is something else here, great attention is paid to the constitutive qualities of assemblages, and how assemblages of things made space in the past. Context here is also linked to social arenas of action in the past. These authors, I would argue, have also done something else in their work: they have demonstrated that the processes by which things were assembled together also carry with them an architectural quality. An example of this would be the way Gomes pays attention to the way in which 27 loomweights were brought together in an area of the site that was recorded in excavated square E10 (2003: 126-131). He described these as elements of material culture that were used in the making of architectural space, and not simply as the remains of a broken loom that was located on the site.

My work on the pottery from Castelo Velho is also contextual, although it takes as its focus the fragmentation of pots and how these relate to the excavated contexts in time. I consider the significance of the temporal trajectory in our evidence, and how it reconfigures accounts of the making and unmaking of space in the Chalcolithic. The previous studies of the spatial distribution of artefacts show how often particular objects occur and the density of particular categories of things, they analyse the presence or absence of artefacts in certain spaces: they are about where things are. The difference is that my work is also about when things are.

\section{THE STUDY OF BROKEN POTTERY}

The emphasis of my research is fragmentation, rather than ceramic form. I am interested in patterns of breakage and deposition. First and foremost, my focus is on post-breakage history (i.e. what happens to pottery after it has been a vessel, but before it is incorporated into a deposit). My aim is to construct sherd stories, to describe the temporality of potsherds, and to get at the immediacy, or distance, between the breaking of a vessel and the deposition of its fragments (see Fig. 6). This study is inspired by the research of two pottery specialists that work on British Prehistory, Mark Knight (in GARROW et al. 2005) and Matthew Brudenell (in BRUDENELL \& COOPER 2008). My main objective is to connect together pottery and architectural studies, and demonstrate that it is the relationship between these that leads to an understanding of the configuration of space, but as actions in time. 


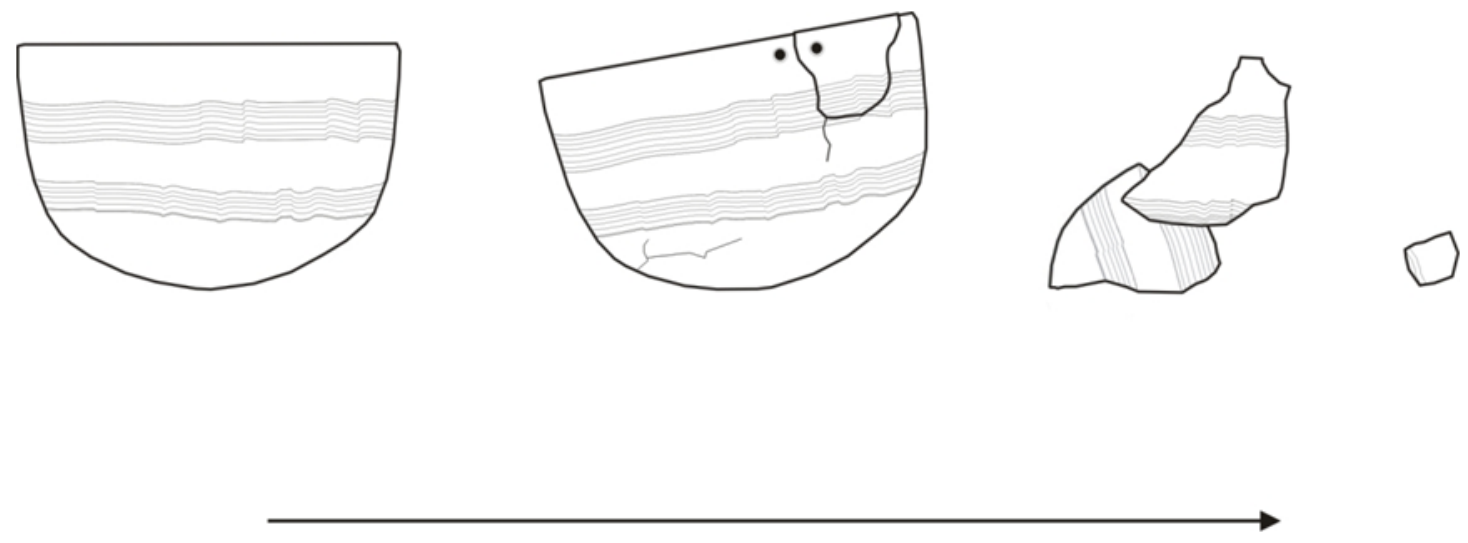

Fig. 6. Pot to sherd - a temporal trajectory.

Fig. 6. Do vaso ao fragmento - uma trajetória temporal.

\section{The character of the assemblage}

In my project I have not studied sherds of pottery to find out information about them as pots. For example, I have not examined the fabric, form and decoration of the sherds in order to think about the manufacture and use of the vessels in any detail, or in order to situate the material typochronologically. This important research has already been carried out on the pottery assemblages, from most of the features, in the work of Oliveira (2003, and in S.O. JORGE et al. 1998-1999) and Baptista (2003). However, I have laid out the sherds in order to study the character of the pottery, as an overall group, in each of the assemblages. First of all, I looked at the number and kinds of decoration; or for any other mark of distinction in the sherds in terms of the shape, form or fabric (e.g. the particular size of the vessel the sherds were from, whether they had been from fine or coarse wares, or from pots made with a distinctive temper); and I examined the number of refitting pieces. This was in order to define a minimum number of vessels that were represented by each group of sherds. I have not done this in order to say exactly how many pots were used in the past, or to say that a particular number of pots were deposited in a feature. Instead, I have used the minimum number of vessels as a rough estimate to gage the degree of what I am comparing, and how to compare it, in the study of patterns of fragmentation in and between features. For example, it makes a difference if a feature is associated with many sherds from a small number of vessels, or a few sherds from several vessels. Similarly, it is important to consider whether the sherds were from large or small vessels: for a larger pot can smash into a larger number of pieces. Furthermore, the degree of fragmentation can be related to whether the pottery is from fine or coarse wares, so I also recorded the number and the weight of the sherds in order to get at the mean sherd weight, and I measured the thickness of each of the sherds. All of these conditions, and the ways in which they are related to one another, have implications for a critical interpretation of patterns of fragmentation, and the significance of the process of fragmentation in the past.

\section{The character of the fragmentation}

The characterisation of an assemblage of potsherds involves looking at the variability and difference between contexts, and what this might be telling us about past practice. The pottery assemblages were studied in terms of the sherds as sherds. Particular attention was paid to the surfaces of the sherds and the degree to which they were worn, or weathered, or burnt. In addition, the broken edges of the sherds were examined and the degree to which these were worn, or weathered, or burnt. I paid attention to whether or not I could identify if the effects on the sherds were carried out pre or post breakage. In addition, the sherds were studied in terms of their number and size and weight, the proportion of rim/body/decorated fragments, and the size of the fragments in terms of a fixed schema of small $(<3 \mathrm{~cm}, \mathrm{~A}) /$ medium $(<7 \mathrm{~cm}$, B) / large $(>7 \mathrm{~cm}, C)$. It should be noted that it is the overall character of each assemblage, the group of sherds that are associated with each feature, that are being studied and explored. Put on very basic terms, how the sherds are as a group, in a particular context. This is important.

The fixed schema that is used to describe the size of the fragments is not being used to interpret fragmentation at the scale of each sherd. Instead, the fixed schema is used to create an overall percentage of the category sizes in each of the pottery assemblages. It is being used to interpret fragmentation at the scale of the feature, and through comparative analysis between features. It should also be noted that databases are used, or made, for each of the assemblages. These databases include information on each individual sherd. Both of these factors contribute to a consideration of how appropriate the fixed schema (small, medium, and large) is for the analysis of patterns of fragmentation. But again, what I want to stress, is that these results are 
an overall percentage from each of the assemblages of pottery. Patterns of fragmentation are not being analysed at the scale of the sherd, or at the scale of the site, but at the scale of the feature. This analysis gets stronger through comparison with other features; the significance of the process of fragmentation is built through the study of many contexts, and the similarities or differences in that detail.

It is essential, at this point, to mention again the work of Oliveira (2003). Oliveira was the first to realise in her study of the pottery from Castelo Velho that patterns of fragmentation are meaningful. In her work she produced a graph of the distribution in the size of the sherds, by length and width, and she demonstrated that there were very rare occurrences of large sherds at the scale of the site (OLIVEIRA 2003: 32). Indeed, from her sample, there were only 7 sherds that exceeded $13 / 10 \mathrm{~cm}$ (width/length). Furthermore, she argued that the majority of the sherds were between $1 / 2 \mathrm{~cm}$ and $6 / 6 \mathrm{~cm}$, in an impressive study of 4039 sherds (her analysis included the pottery from $\mathrm{I} 7, \mathrm{~J} 7, \mathrm{~B} 6, \mathrm{C} 5$, C6, C7, C8, D5, D7, D9, E11, A14, A12, I9, J8, J9, H14, H15, I13, I14, I15, J10, J12, J13, J14, B20, C19, C20, F18, G18 and G19). However, I argue that in order to consider the significance of the size of that majority of sherds, and the detail that resides there, it is necessary to change the scale of the analysis from that of the site to that of the feature, and this is something that I do here.

In summary, my analysis is contextual: it is fixed at the scale of each of the excavated features and subsequently between features. The work involves the characterisation of each assemblage as a whole, and then the distribution of overall percentages of sherd sizes and the level of abrasion on sherds. In line with Brudenell, it will be argued that:

'This variability in assemblage composition suggests that fragments which ultimately came to be deposited together had probably undergone relatively diverse post-breakage histories' (in BRUDENELL \& COOPER 2008:22).

Furthermore, I argue that the temporal qualities of the activities that involve pottery will open up a new way in which to see architectural practice at the site of Castel Velho.

\section{THE CHARACTER OF THE ASSEMBLAGES \\ Pit}

There were no whole vessels (out of 312 sherds there were only 19 rim fragments or $6.1 \%$ of the total assemblage). The largest rim represented only $5 \%$ of its total circumference. The fragmentary nature of the pottery suggested that, at best, only a few vessels were represented by perhaps a third to a half of their original form. Furthermore, the majority of vessels seemed to be represented by just a couple of sherds. For example, there were occurrences of distinctly decorated rim sherds that existed in isolation. There was a perforated sherd (208) from a post-firing repair hole, alongside worn vessels, which indicate that there were pots that already had extended histories prior to breakage. The assemblage included approximately 18 different decorative schemes, and 3 distinctive plain medium-sized rims stood out. The sherds potentially represent the fragmentary remains of at least $20-25$ vessels.

The assemblage included fresh, slightly softened, abraded, weathered, partially burnt and heavily burnt fragments. The variation in condition applied to all types of pottery (i.e. decorated fine wares and coarse wares-regardless of sherd thickness). The small number of actual refits between sherds points towards the material coming from an already fragmented accumulation, but at the same time indicates a common source. Possibly, sherds of 'domestic' - bowls and cups - had been dumped together in an accumulated mass, and then a part of that accumulation of material was then redeposited in the pit some time later. This means that there was a playing out of time between the breaking of pots, the accumulation of sherds, and the deposition of sherds in the pit. The pit is more closely associated with a group of mixed sherds than a series of particular pots, and these sherds came from a common source.

\section{Structure with Bone}

There was one vessel that was three quarters complete, but the rest of the material from the assemblage was not composed of whole vessels (out of 353 sherds there were only 21 rim fragments). This assemblage also included fine ware bowls with fingernail decoration, coarse ware vessels with applied bosses (raised decoration), punctate decoration, and perhaps a greater degree of sherds with a burnished finish (this included light fluting or even grooved decoration). Perhaps we can say that this assemblage included less 'familiar' forms. For example, sherd (327) had a raised boss and incised line decoration forming 'panels', sherd (207) had a distinctive incised comb decoration that was made up of a short 'drag-and-stab' motif of 3 thick prongs.

The biggest sherd size was $175 \mathrm{~mm} \times 140 \mathrm{~mm}$, $11 \mathrm{~mm}$ thick, $370 \mathrm{~g}$ and was plain but burnished (40 -45); and amongst the smallest sherds there was a fine ware sherd size $25 \mathrm{~mm}$ x $14 \mathrm{~mm}, 4 \mathrm{~mm}$ thick, $2 \mathrm{~g}$ and was decorated (70). The predominant sherds were plain body pieces. The assemblage included multiple refits. Sherds $(31)$ and $(34,35,36)$ refit with sherds that were recovered from outside of the structure: (2028) from H11 and (1703) from B12. In addition, there were vessels that were represented by just one distinctively decorated sherd. Approximately 18-20 vessels were recognisable from within the assemblage. 


\section{Structure with Seeds}

There were no whole vessels (out of 301 sherds there were 21 rim fragments or $6.9 \%$ of the total assemblage). The assemblage included approximately 8 different decorative schemes done by comb. Three vessels stood out because of the large size of the sherds, and because they produced immediate refits. Two of those vessels indicated obvious pre and post-breakage histories. Of the 3 vessels a quarter to a half of the pot was represented (as illustrated by the lack of rims: 1, 2 and 4 rim sherds respectively to each of the vessels).

Vessel A: 11 sherds $(253,277$, M1(x4), 324, $325,326,327$ and 328), all of which were decorated with the same broad band light comb (simple horizontal lines, c. $40 \mathrm{~mm}$ wide band). The comb decoration was so light it had the appearance of being from a brush stroke. It had a simple rounded rim and was a simple slightly closed bowl profile. 4 sherds showed definite evidence of being burnt post-breakage as discolouration caused by refiring went across the sherd breaks $(325,326,327$ and 328). These same sherds also display patches of external surface wear that appear to have occurred during the use of the vessel. Significantly, an adjoining sherd (324) did not display the same pale grey colouring suggesting that it was not burnt, but it also retained an area of post-breakage abrasion along the edge where it refitted with 327-328.

Vessel B: 24 sherds $(214,213,215,302,304$, $305,300,301,247,248,156,42,243,157,249$, $267,9,288,289,290,245,246,216,35)$. It was a simple bowl form with a burnished finish decorated with fine-toothed comb wave, in places chaotic, c. $25 \mathrm{~mm}$ wide bands). In contrast to the previous vessel there was no evidence for burning and the sherds looked to be in a fresh state.

Vessel C: 9 sherds $(295,296,292,293,105$, $294,113,169,172)$. Slightly flared profile with a simple rim, decoration was narrow bands $\mathrm{c} 12 \mathrm{~mm}$ of 'drag-and-stab' comb. A large body sherd made up of 295-296 had a burnt edge.

The biggest sherd size was $135 \mathrm{~mm} \times 100 \mathrm{~mm}$, $13 \mathrm{~mm}$ thick, 226g and was decorated (324); and amongst the smallest sherds there was a decorated rim size $21 \mathrm{~mm} \times 19 \mathrm{~mm}, 6 \mathrm{~mm}$ thick, $2 \mathrm{~g}$ and was decorated (200). There was a coherency to the assemblage (i.e. no 'odd' sherds as with the structure with bone). The predominant sherd type was a plain body sherd. In general, the assemblage was made up of fresh unabraded fragments of pottery. However, the assemblage also includes occasional pieces with worn outer surfaces (pre-breakage), and burnt edges (post-breakage). Approximately 812 vessels were recognisable from within the assemblage.

Fragments of 'domestic' - bowls and cups but from a much smaller number of vessels, had been dumped nearer in time to the act of deposition. Although the period of time between the breaking and the depositing of the pottery was shorter, the assemblage was still only partial. Furthermore, there are sherds that refit, but with some of those sherds having been burnt and the other not. Therefore, after this pot had broken, some of the sherds got caught up in activities that involved fire, whilst others did not, but then both sherds were collected up and deposited in the structure. Although the sherds refit, they demonstrate different post-breakage histories.

\section{Two Hearths}

There were no whole vessels (out of 533 sherds there were only 38 rim fragments or $7.1 \%$ of the total assemblage). However, the largest rim represented about $25-33 \%$ of its total circumference. The less fragmentary nature of the assemblage suggested that several vessels were represented by perhaps a third of their original form. Furthermore, the majority of vessels seemed to be represented by several sherds. A comparison of the mean sherd weight from each of the features, and a subsequent comparison of the thickness of the sherds across the features, demonstrated that there were a large number of sherds from vessels with thin walls, indicating a higher number of fine wares. Potentially the sherds represented the fragmentary remains of at least $20-25$ vessels.

The assemblage included fresh and slightly softened fragments, and it was notable that it was missing the abraded and heavily burnt fragments of the pit context. The homogeneity in the condition of the pottery applied to all types (i.e. decorated fine wares and coarse wares - regardless of sherd thickness). The pottery was homogeneous in character in comparison to the context of the pit, and composed of larger fragments. Generally, the larger fragments found in this 'open' context, and the fresher breaks, suggest a greater immediacy to their deposition. Sherds of 'domestic' - bowls and cups (many were fine wares) - had been dumped closer in time to the breaking of the vessels. However, although the period of time between the breaking and the depositing of the pottery was shorter, the assemblage was still only partial, and this material was broken before it was deposited. It is interesting to note that the sherds, and the breaks on the sherds, were not obviously burnt even though they came from a hearth context.

\section{THE CHARACTER OF THE FRAGMENTATION}

The minimum number of vessels from each feature is comparable in the assemblage from the pit with 20-25 vessels, the assemblage from the Two Hearths 20-25 vessels, and the 18-20 vessels from the Structure with Bone. The minimum number of vessels is smaller in the assemblage from the Structure with Seeds, with 8-12 vessels represented. 
Although the kinds of decoration on the pottery were very different from the Structure with Seeds and the Structure with Bone, the mean sherd weight (MSW) from both of these assemblages were similar (see Fig. 7). And although the decorated pottery from the Structure with Bone stood out as distinctive, the MSW was greater than that from the Two Hearths (see Fig. 7).

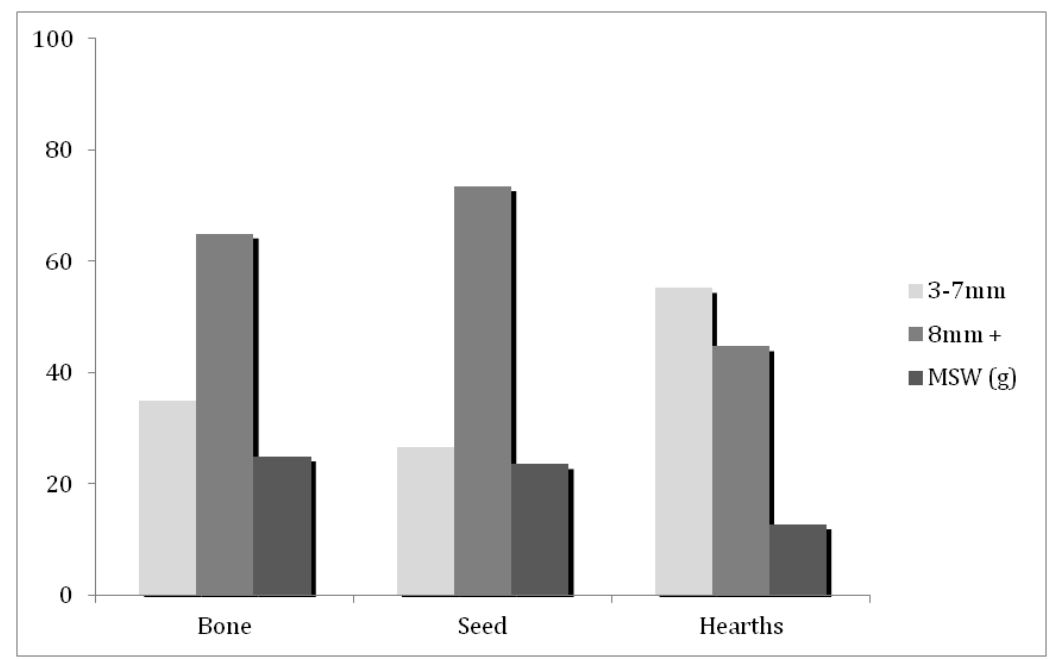

Fig. 7. Sherd thickness in comparison with Mean Sherd Weight (MSW) by percentage. Fig. 7. Relação entre a espessura e o peso médio (MSW) dos fragmentos cerâmicos.

In order to explore why these assemblages had a different MSW, I looked at the sherd thicknesses. Figure 8 demonstrates, that in a range from $3-17 \mathrm{~mm}$, the context of the Two Hearths was made up from the finer wares. The Two Hearths pottery formed a distinctive grouping from $5-8 \mathrm{~mm}$, then there was the Structure with Bone from $7-9 \mathrm{~mm}$, followed by the Structure with Seeds from $8-9 \mathrm{~mm}$. The pottery from the context of the Two Hearths is offset and to the left of the measurements from the other two contexts.

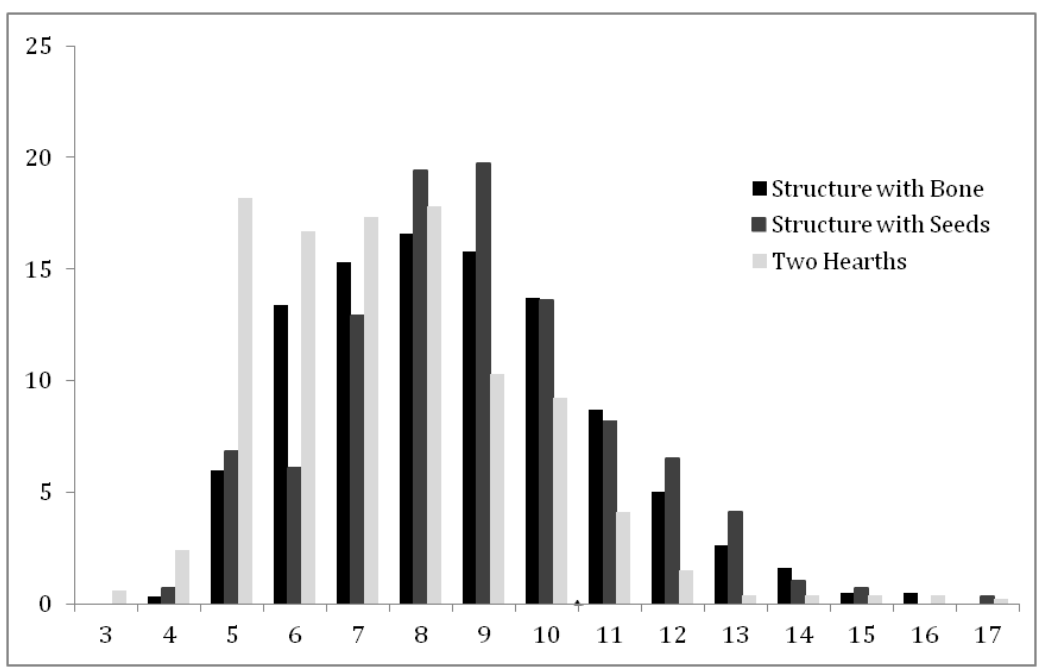

Fig. 8. Sherd thickness in comparison with frequency of occurrence.

Fig. 8. Comparação entre a espessura dos fragmentos e a frequência de ocorrência de fragmentos cerâmicos na Estrutura com Ossos Humanos, Estrutura das Sementes e no Contexto com duas lareiras localizadas nas quadrículas C5 e C6.

In more detail, Figure 9 demonstrates how the ranges of pottery between the Structure with Bone and Structure with Seeds overlap.

However, it is important to note that in the 'open' context (Two Hearths), and all three of the 'closed' contexts (Structure with Seeds, Structure with Bone, Pit), the pottery assemblages were composed from roughly the same proportions of rim to body to decorated sherds (see Fig. 10). This continuity across contexts creates a baseline from which to compare and assess the patterning in the fragmentation of the pottery. 


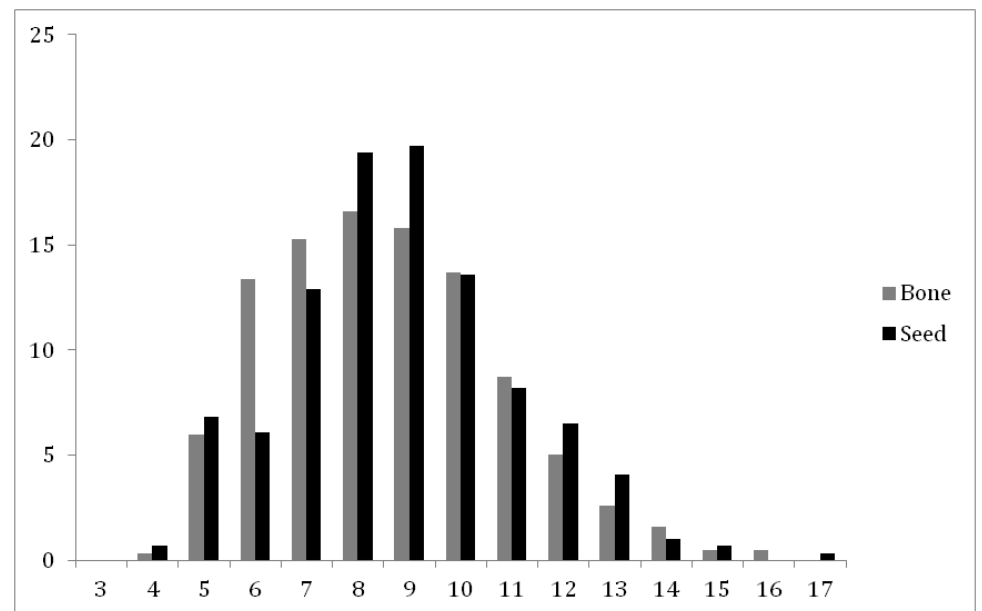

Fig. 9. Sherd thickness in comparison with frequency of occurrence.

Fig. 9. Comparação entre a espessura dos fragmentos e a frequência de ocorrência de fragmentos cerâmicos na Estrutura com Ossos Humanos e na Estrutura das Sementes.

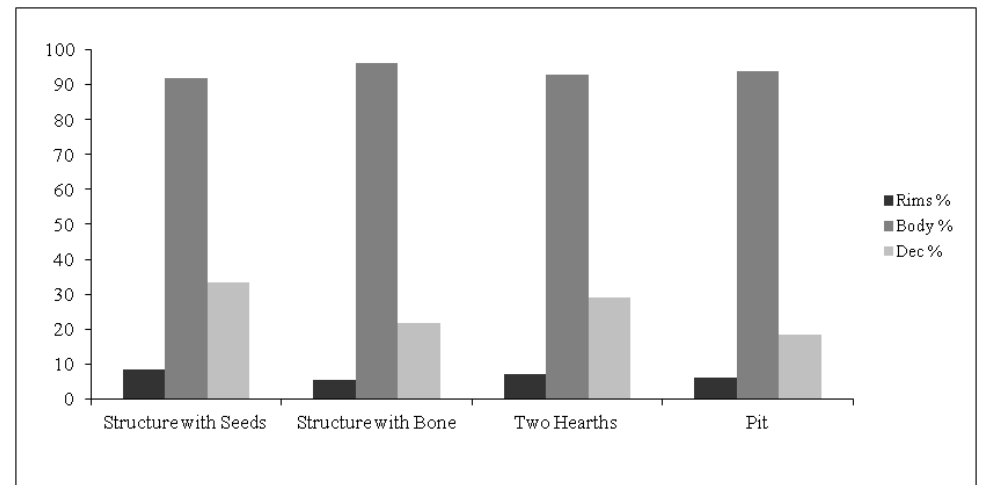

Fig. 10. Percentages of rim to body to decorated sherds.

Fig. 10. Percentagens de bordos, panças e fragmentos decorados nos diversos contextos: Estrutura com Sementes, Estrutura com Ossos Humanos, Contexto das duas lareiras e Fossa.

In terms of the size of the fragments, Figure 11 demonstrates that all of the contexts had very few large sherds $(>7 \mathrm{~cm}, \mathrm{C})$. However, there was a remarkable difference in the number of small $(<3 \mathrm{~cm}$, A) to medium $(<7 \mathrm{~cm}, \mathrm{~B})$ size sherds between the Pit; and then the Structure with Seeds, Structure with Bone, and the Two Hearths. Indeed, the results from the Pit are the mirror image of the results from the other three contexts; the results are the opposite of each other. There is also a striking similarity in the pattern of fragmentation from the 'closed' contexts of the Structure with Seeds, Structure with Bone, and the 'open' context of the Two Hearths. The fresh nature of the breaks of the sherds, from these three contexts, indicates a shorter period of time between the breaking of the vessels and their deposition.

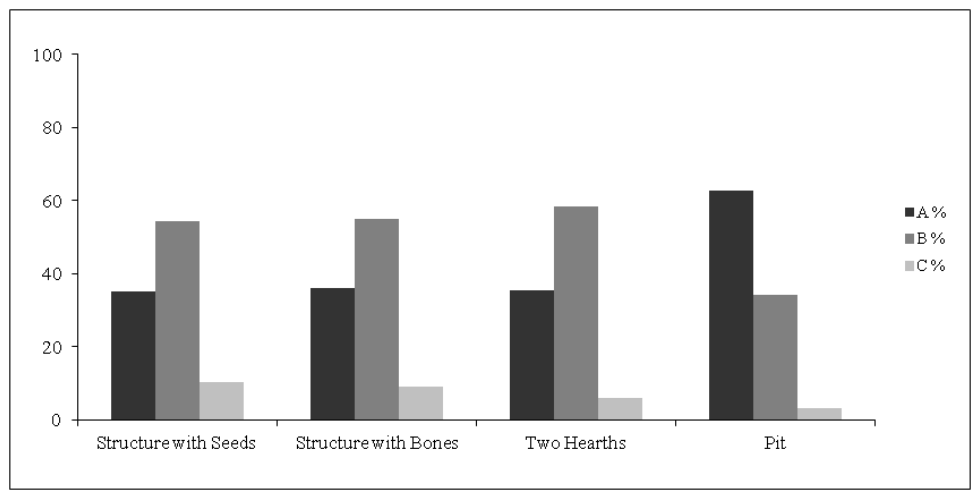

Fig. 11. Distribution of Small (A), Medium (B), and Large (C) sizes of sherds across the four contexts by percentage.

Fig. 11. Distribuição dos fragmentos de pequena (A), média (B) e grande (C) dimensão pelos quatro contextos em estudo (percentagens). 


\section{THE SIGNIFICANCE OF THE PROCESS OF FRAGMENTATION IN THE PAST}

Pit

The interpretation of variation in the fragmentation patterns between different kinds of contexts tells us something about past practice. This analysis demonstrates that a 'closed' context (Pit) contained pottery that had accumulated somewhere else before it was deposited. However, although the material came from an already fragmented accumulation, the character of the pottery and the number of refits indicated a common source. This research also brings time into play in terms of how archaeologists interpret contexts, for example with the Pit context there was a gap in time between the breaking of pots and the deposition of sherds. This is a new strand of thinking on the nature of the relationship between 'in situ' artefactual material and the archaeological feature. Similarly, this research hints at unseen features such as accumulations of material prior to deposition (i.e. middens). Analysis on the pottery identifies and highlights a missing context, and not just the features that were physically seen and recorded during excavation. This investigation shows that the 'open' context (Two Hearths), Structure with Seeds, and Structure with Bone had a consistently larger proportion of medium size sherds, and this, and the homogenous character of the pottery, and the greater number of refits, suggested more of an immediacy to their deposition. Therefore, as well as introducing different kinds of time into the evidence, this analysis calls into question what we mean by a 'closed' context. It was noted on excavation, and drawn in plan, that the pit contained four concentrations of pottery, and it was argued that the pottery had been deliberately arranged. My research now asks the question: what does it mean when people in the past arrange material rather than objects? Pottery that had broken a long time before its deposition, a group of mixed sherds that were no longer recognizable as being from particular pots, and that had come from a fragmented accumulation of material, seemed to be arranged in concentrations in a pit. In addition, these circumstances would seem to highlight another gap, a gap in how we approach the study of material culture in prehistory. This evidence would seem to sit between interpretations of practices that deal with rubbish, and understandings of the biographies of particular objects.

\section{Two Hearths}

The similarity in the patterns of fragmentation between the Structure with Bone, Structure with Seeds, and the Two Hearths, also support the findings of Oliveira (2003) when she stated that the stratigraphy of the Two Hearth context was complex. Oliveira (2003: 108) argued that this context was to do with the closure of an entrance and the transformation of a walled architecture. The freshness of the breaks in the sherds of pottery, and the suggested relative immediacy of their deposition, would add a temporality to this account with there having been little time between the deposition of broken artefacts and slabs of blue schist, and then the blocking of the passageway and the construction of a section of walling. These things are connected in time, and I would add that the associations between material were not only connected to a walled architecture but that they seemed to have made space on more of their own architectural terms: they did not simply fill a gap. A study concerning spatialising operations needs to work in a way that connects material culture studies to architectural histories without simply reducing things down to statements where objects were placed in the spaces created by buildings . The pottery studies tell us much more than that, the pottery was broken when it became associated with the hearths, but it was not noticeably burnt. So the fires were no longer lit? The sherds had fresh breaks, which tells us that there is less time involved between the breakage of pots and there deposition, but it also tells us that there was little time between the deposition of sherds and the addition of the blue schist, for the blue schist closed the context and preserved the condition of the sherds. I have also noted that this assemblage is constituted from a much larger number of fine wares than were found in the other assemblages.

\section{Structure with Seeds}

In the Castelo Velho archive there are drawings and descriptions at small registers of scale. S.O. Jorge has termed this work, research into moments (S.O. JORGE et al. 1998-1999). Moments are constructed from detail revealed during the excavation and post-excavation of a particular feature. This scale is the time and space of the archaeological context, and relates most directly to the time and space of depositional practice in the past. An example, is Lídia Baptista's (2003) study of the assemblage of pottery from the Structure with Seeds, she did most of the refitting work on this pottery, and she carried out an in-depth study of the spatial distribution of the sherds in association with the charred seeds that were recovered from this context. She has shown, through the spatial distribution of the sherds, that the largest number of fragments were within the uppermost context (Moment 6), and that these were associated with stones that were closing elements of the structure (BAPTISTA 2003: 143). This makes an interesting parallel with the pottery from the Two Hearths that were also caught up in a process of closure. Baptista also notes that with some of the vessels, where it was possible to 
make refits, there was a regular distribution, but in other cases the pieces were dispersed (ibid). In addition, in the areas where there were concentrations of charred seeds, there is a physical relationship between seeds and sherds, where it looks like pottery contained the seeds, but where the sherds were actually dispersed fragments without closely associated or regularly distributed refitting pieces.

Six moments of deposition were recognized (with no material culture having been incorporated into the first moment), and it was shown that the sherds did not represent whole vessels, and that they did not enter the structure holding grain. From the material and the spatial details, it was suggested that wrapped in the stone structure (within Moments 2, 3 and 4), fragments of pottery and seeds had been handled as dynamic components that referred to the storage of goods, but that did not directly materialise as that (BAPTISTA 2003: 144). This is an interesting point, but what about time? What do the different temporal dimensions do to our study? It was with this in mind that I decided to carry out a study of the pattern of fragmentation within the structure at the scale of each moment of deposition.

\section{THE CHARACTER OF THE FRAGMENTATION THROUGH THE STRUCTURE WITH SEEDS}

Figure 12 utilises the findings of Baptista (2003), but in a different format, that the largest amount of pottery was deposited in the uppermost contexts. In addition to this, Figure 13 shows the percentages in the size of the fragments that were caught up in each of the six moments of practice (i.e. the pattern of fragmentation). In Moment 6 and Moment 4, the distribution of small, medium and large sherds, suggest that there was a relatively short period between the breakage and the deposition of the pottery. Furthermore, there were no moments in which this situation was reversed, as had been the case with the assemblage from the Pit (with its evidence for a greater period of time between the breaking and the deposition of pottery). In Moment 5 and Moment 3, the percentages of small and medium sized sherds are much closer, and in Moment 3 and Moment 2 there are no large size sherds at all. Therefore, there was not only a higher proportion of sherds in the upper context, they were also larger sized sherds, and the further you move down through the structure the results demonstrate that there was a smaller proportion of pottery and smaller sized sherds.

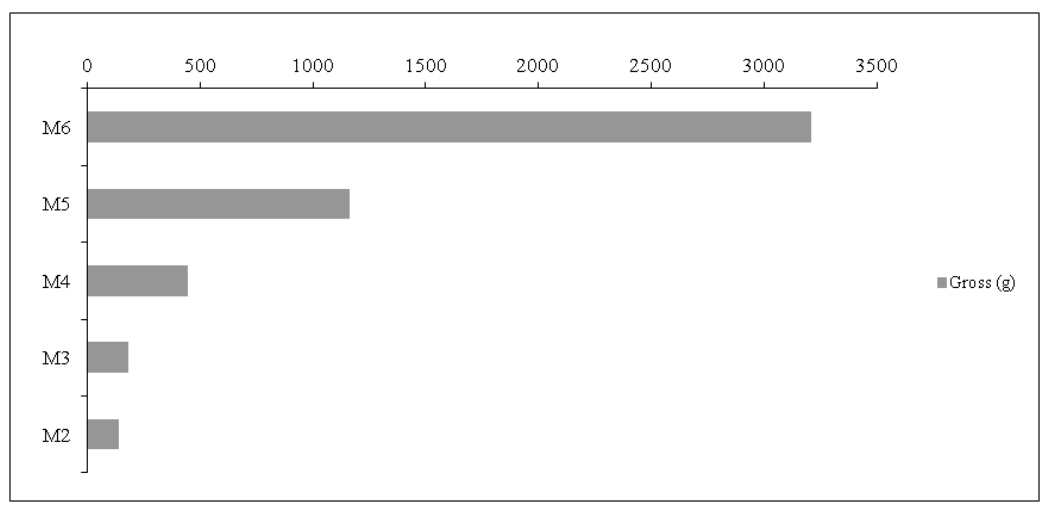

Fig. 12. Distribution in the amount of pottery by weight, across five moments.

Fig. 12. Distribuição dos fragmentos cerâmicos por peso (em gramas), nos cinco momentos identificados na Estrutura das Sementes.

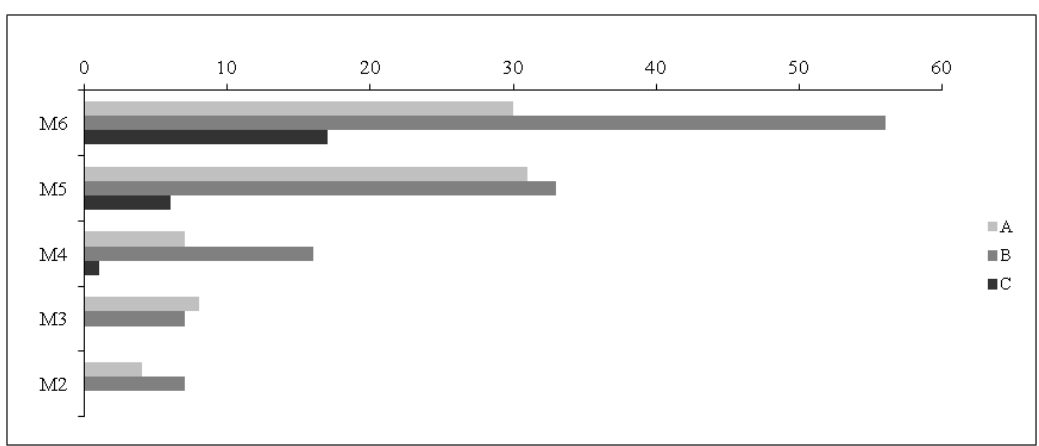

Fig. 13. Distribution of Small (A), Medium (B), and Large (C) sizes of sherds, across five moments.

Fig. 13. Distribuição dos fragmentos cerâmicos pequenos (A), médios (B) e grandes (C) nos cinco momentos identificados na Estrutura das Sementes. 
Figure 14 adds to the pattern of fragmentation in each moment, by showing the refitting pieces, and the freshness of the sherds.

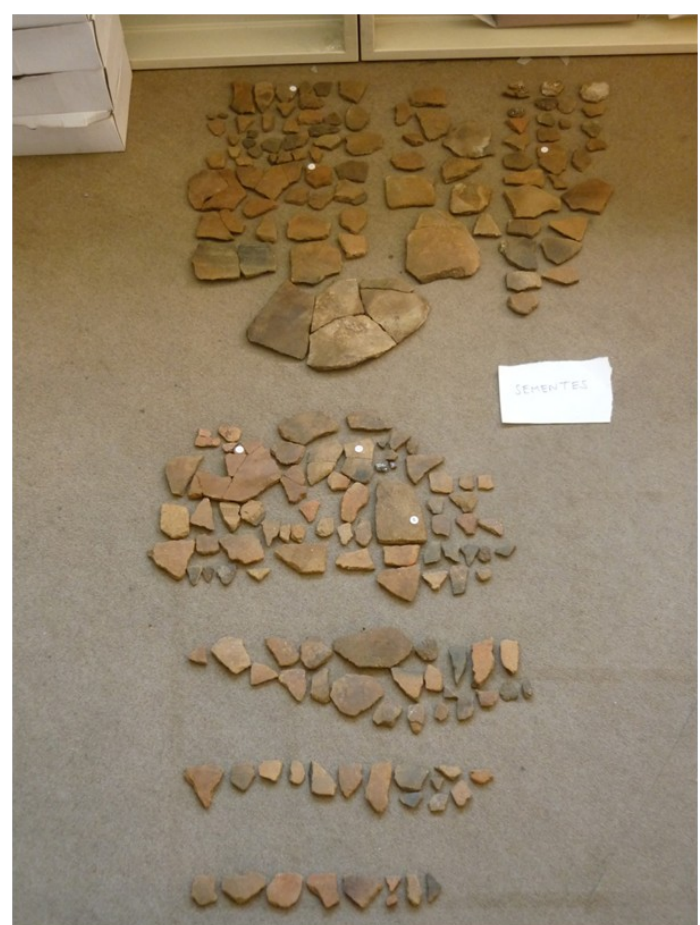

Fig. 14. Pottery arranged into the five moments in the Structure With Seeds.

Fig. 14. Fragmentos cerâmicos da Estrutura com Sementes divididos pelos cinco momentos identificados.

The feature also contained clumps of charred seeds, another indicator of a short gap between object and deposition, but the seeds were not contained within the pots. However, the temporality of the clumps of charred seeds can still be used to think about the temporality of the pottery. In general, the assemblage was made up of fresh unabraded fragments of pottery, but also included pieces with worn surfaces (that had occurred prebreakage) and burnt edges (that had occurred postbreakage). There was also a coherency about the assemblage (i.e. no 'odd' sherds). And there were 11 sherds from one particular pot, all of which were decorated with the same broad-band light comb. Four sherds showed definite evidence of being burnt post-breakage as discolouration caused by refiring went across the sherd breaks. These same sherds also displayed patches of external surface wear that appeared to have occurred during the use of the vessel. Significantly, though, an adjoining sherd did not display the same pale grey colouring suggesting that it had not been burnt, whilst it retained an area of post-breakage abrasion along its refitting edge (see Fig. 15).

So we can unwrap and then rewrap these practices in a different way. A small group of pots, including vessels that had signs of extended useware, had been broken. Between breakage and deposition some of the sherds were involved in another kind of practice, one that involved fire, just like the seeds. But then both burnt and unburnt sherds, along with the charred seeds, were brought together and deposited in the stone structure (presumably the organic un-burnt seeds are missing because of post-depositional processes). Here different temporal dimensions overlap, wrapping these things together in a structure, connecting one time with another. The small details from the fragmentation of the pottery, and the nature of the breaks of the sherds, remind us of another time, between breakage and deposition, and another space, between pot and structure, where not too long after breaking, some sherds were burnt, perhaps along with the seeds, and others were not and before all of these things were deposited together in the structure.

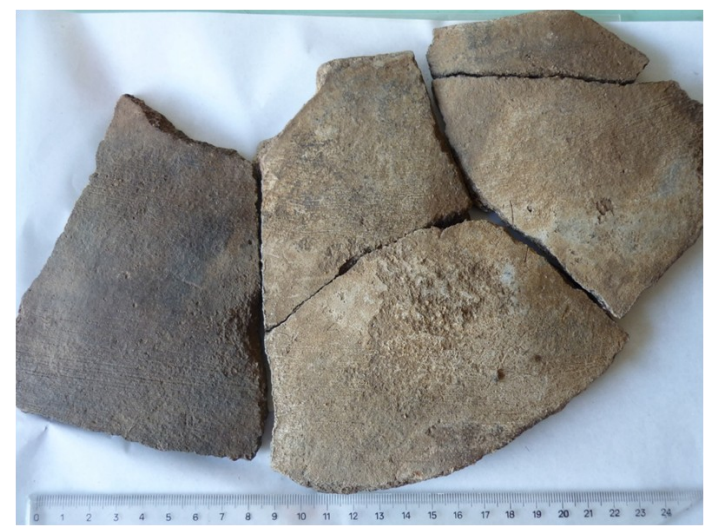

Fig. 15. Vessel A from the Structure with Seeds.

Fig. 15. Vaso A da Estrutura com Sementes.

\section{THE CHARACTER OF THE FRAGMENTATION THROUGH THE STRUCTURE WITH BONE, PART OF THE RAMP, AND CONTEXTS UNDER THE RAMP}

An important context on the site of Castelo Velho is the Structure with Bone, due to the nature of this evidence, with human burials in the feature, it is a context where 'domestic' and 'ritual' interpretations must be thought through. It is also at a point in the site where many sections of architecture meet but do not connect sequentially: there are the features under the ramp, the ramp, the structure with human bone, and the use of the protruding bedrock. It was not possible, as things stood, to know whether the important structure with bone related to the ramp or to the activities that took place underneath it, or to both of these contexts, or to other contexts. It was important, therefore, to undertake a study of the patterns of fragmentation from these contexts, and attempt a refitting programme of the pottery. However, the ramp (and the zone under it), 
were areas of construction rather than small-scale features like the Structure with Bone. I examined pottery from the ramp in H12, H13, H14, H15, I12, $\mathrm{I} 13$, I14, I15, J12 and J13; and under the ramp in H14, H15, I13, I14, I15, J12, J13, and J14. It should also be noted that the sizes of the assemblages were different. There were 353 sherds of pottery recovered from the Structure with Bone, 427 sherds from the portion of the ramp, and 1222 sherds from underneath the ramp. Yet in all of the contexts the pottery assemblages were composed from roughly the same overall proportions of rim to body to decorated sherds (see Fig. 16). This continuity across contexts acts as a baseline from which to compare and assess the patterning in the fragmentation of the pottery.

In terms of the size of the fragments, I have already commented on the similarity in the pattern of fragmentation from the Structure with Bone,
Structure with Seeds, and Two Hearths (see Fig. 11). The signature to these contexts contained very few large sherds $(>7 \mathrm{~cm}, \mathrm{C})$, and then a large proportion of medium sized sherds $(<7 \mathrm{~cm}, \mathrm{~B})$ over small ones $(<3 \mathrm{~cm}, \mathrm{~A})$. It is hardly surprising that the pattern of fragmentation from in and under the ramp is different, for the sherds were not recovered from similar 'closed' contexts. However, what is interesting, the pattern of fragmentation from the area Under the Ramp is the opposite of that from the Structure with Bone. In fact the signature to the context Under the Ramp is the same as that of the Pit. What is more the signature to the Ramp itself stands out as different to both Structure with Bone and the area Under the Ramp. This is the first time that we have seen a signature that contains a near equal proportion of medium and small sized sherds (see Fig. 17).

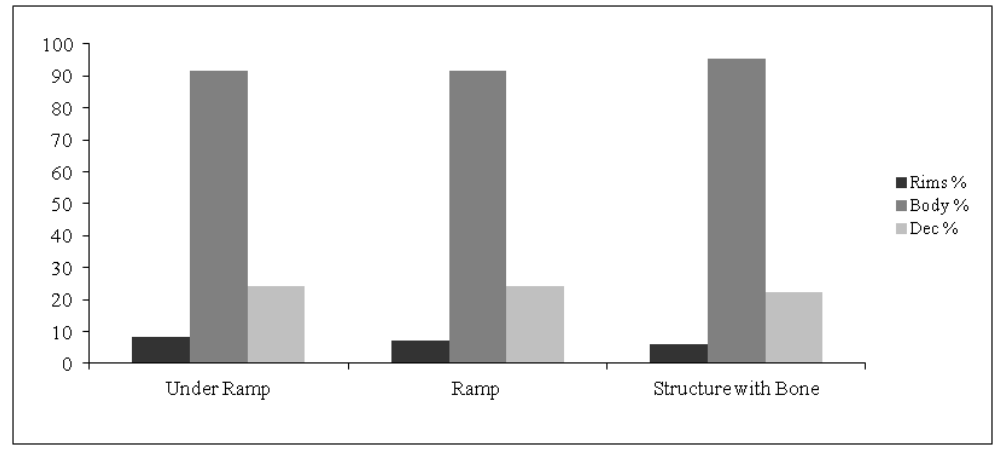

Fig. 16. Percentages of rim to body to decorated sherds.

Fig. 16. Percentagens de bordos, panças e fragmentos decorados nos três contextos em estudo - sob a Rampa, Rampa e Estrutura com Ossos Humanos.

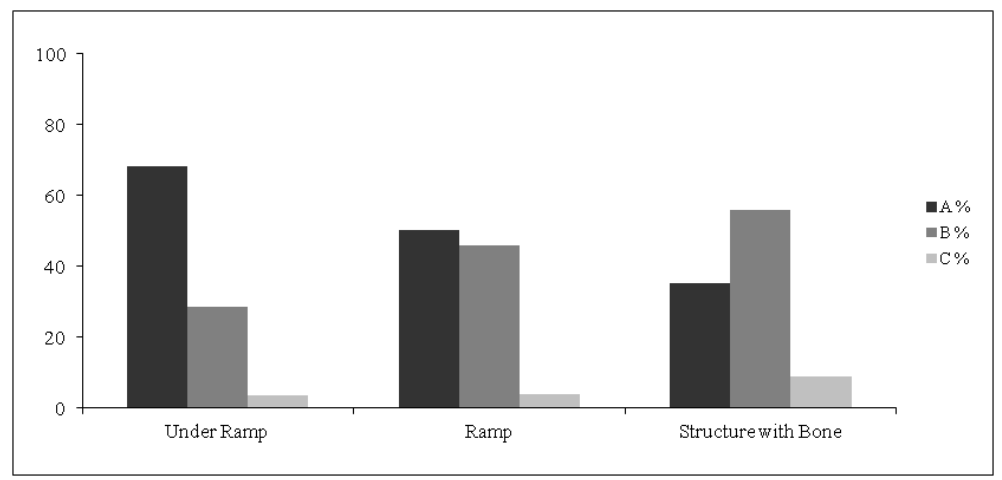

Fig. 17. Distribution of Small (A), Medium (B), and Large (C) sizes of sherds across the three contexts by percentage.

Fig. 17. Distribuição dos fragmentos de pequena (A), média (B) e grande (C) dimensão nos três contextos (sob a Rampa, Rampa e Estrutura com Ossos Humanos), em números percentuais.

Oliveira has noted that the in the area Under the Ramp most of the pottery was recovered from quadrants J13, J14 and I14 in the vicinity of a structure that was 'clean' of artefacts (2003: 84). The spatial focus to her work means that she has picked up on the significance of the density, and presence and absence of sherds, but my analysis adds a temporal understanding to her findings. The comparable signature from Under the Ramp and the Pit, suggests the pottery recovered from the quadrants had accumulated somewhere else before it was deposited. The spatial gap in artefacts, from a structure 'clean' of artefacts, is also an extended temporality. As with the Pit, although the material from Under the Ramp came from an already fragmented accumulation, the character of the pottery, and the number of refits indicated a com- 
mon source. There was a gap in time between the breaking of pots and the deposition of sherds outside of the structure, especially in J13, J14 and I14. But this is not a straight story, from the use of the pottery inside the structure, to it becoming broken and being deposited outside. For the sherds had lain broken for some time before they were deposited there, and they had lain broken as part of a larger grouping of things somewhere else before they were deposited. It is interesting that the structure was described as being 'clean' of artefacts, and maybe this is where the broken material had previously accumulated before part of it was later deposited outside, with the structure then having been cleaned out. But this would also mean that the rest of the accumulated material was taken elsewhere too. Although the spatial focus of Oliveira's work noted that there was a larger density of sherds in quadrants J13, J14 and I14 (2003: 84), the fragmentation of the sherds was dominantly of small size across all of the quadrants (see Fig. 18).

The Ramp itself, although constructed from a series of different techniques, was made out of stone and tamped clay, and with very few fragments of material culture caught up in that mix (e.g. only 427 sherds of pottery were recovered from a portion of the Ramp as opposed to 1222 sherds Under the Ramp).
What is more, the pattern of fragmentation does not completely suggest that the pottery was from sherds that were simply lying around on the surface and that were a bi-product of earth and clay extraction, for small sized sherds do not dominate the assemblage (see Fig. 17). Instead, overall the Ramp material has a signature of almost equal small and medium sized sherds. The assemblage included fresh, slightly softened, abraded, weathered, partially burnt and heavily burnt fragments. The variation in condition applied to all types of pottery (i.e. decorated fine wares and coarse wares-regardless of sherd thickness). However, within the bags of pottery, there were a large number of sherds of homogenous character that had a greater number of refits. There are then, a surprising number of fresh, homogenous, refitting, medium sized sherds of pottery in a situation where material culture is directly caught up in the construction process of the Ramp. In more detail, Figure 19 demonstrates that there was an equal proportion of small and medium sized sherds in quadrants H14, I12 and J13, with a higher proportion of medium sized sherds dominant in H12, I15 and J12. There are, therefore, areas within the Ramp that suggest that there was more of an immediacy to the deposition of the sherds.

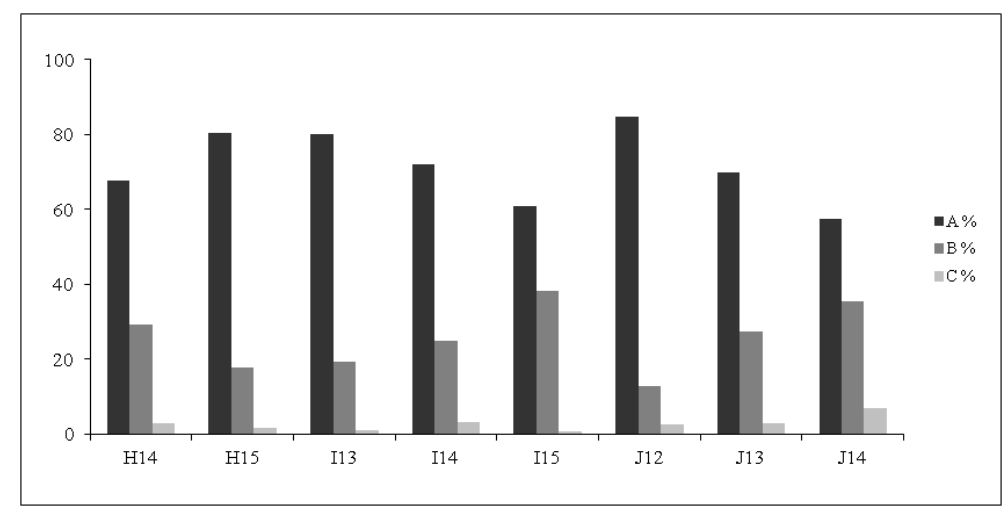

Fig. 18. Distribution of Small (A), Medium (B), and Large (C) sizes of sherds across the quadrants (Under the Ramp) by percentage.

Fig. 18. Distribuição dos fragmentos de tamanho pequeno (A), médio (B) e grande (C) pelas quadrículas sob a Rampa, em números percentuais.

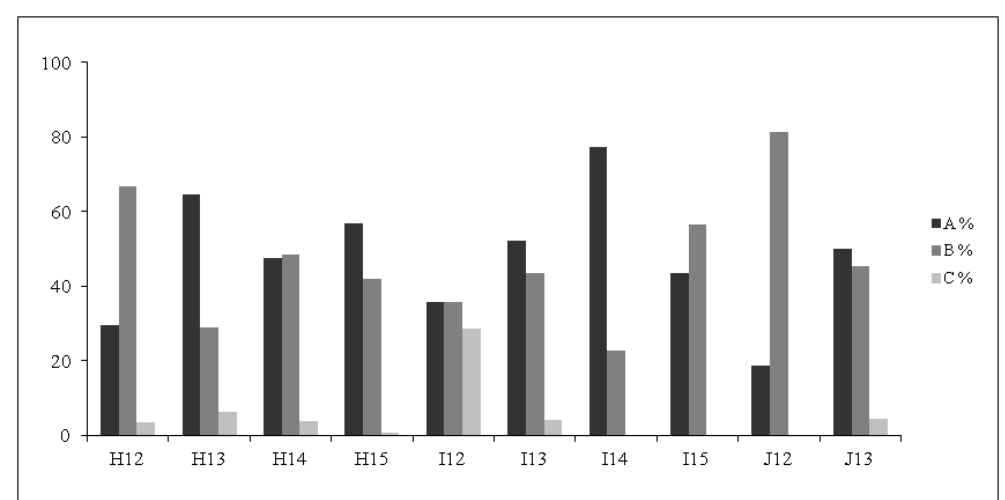

Fig. 19. Distribution of Small (A), Medium (B), and Large (C) sizes of sherds across the quadrants (Ramp) by percentage.

Fig. 19. Distribuição dos fragmentos de tamanho pequeno (A), médio (B) e grande (C) pelas quadrículas analisadas da Rampa, em números percentuais. 
10. REFITTING PROJECT THROUGH THE STRUCTURE WITH BONE, PART OF THE RAMP, AND CONTEXTS UNDER THE RAMP

I attempted a refitting programme of the pottery across H12, H13, H14, H15, I12, I13, I14, I15, $\mathrm{J} 12, \mathrm{~J} 13, \mathrm{~J} 14$, and J15 from both Ramp and Under the Ramp contexts, with the Structure with Bone. Figure 20 shows the sherds from five quadrants from Under the Ramp that were laid out for this purpose.

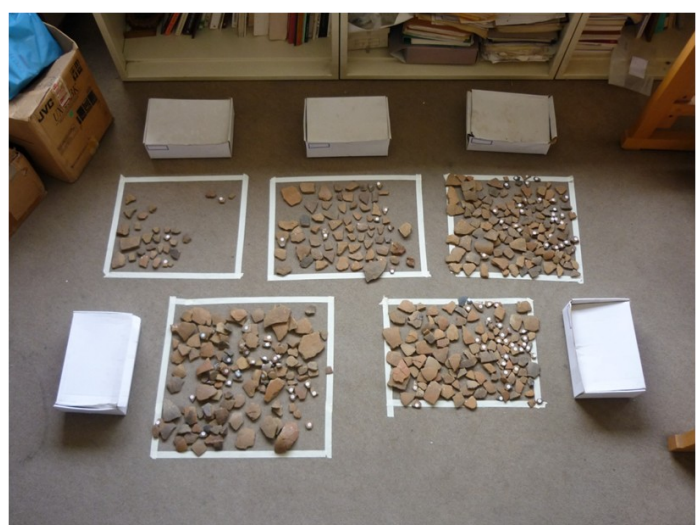

Fig. 20. Pottery from I13, I14, I15, J13 and J14 Under the Ramp.

Fig. 20. Fragmentos cerâmicos provenientes das quadrículas I13, I14, 1 15, J13 e J14, identificados sob a Rampa

There were no refitting pieces between the area Under the Ramp and the Structure with Bone. Although this is hardly surprising now that we know that the material Under the Ramp had been broken and accumulated for some time before it was deposited. There were no refitting pieces between the Ramp and the Structure with the Bone either. Maybe the Structure with Bone was a later insertion after all. In the course of my work on this post-excavation archive, I came across a box of odd sherds of pottery from different contexts, and from this material I made two refits with pieces from the Structure with Bone immediately (I was either very lucky that a researcher had pulled out interesting vessel types that refitted with my material or, indeed, someone had made these refits already in their own work). Sherds $(31)$ and $(34,35,36)$ refit with sherds that were recovered from outside of the Structure with Bone: (2028) from H11 and (1703) from B12 (see Figs. 21 and 22). In addition, these are sherds from vessels that are represented by just one distinctively decorated sherd in the Structure with Bone. It should be remembered that the Structure with Bone was a partly enclosed feature, and it was left open on its eastern side. It is not of any real surprise then that the first refit was from the quadrant directly to the east of the Structure with Bone, in H11. However, the second refitting piece was recovered from a quadrant approximately $14 \mathrm{~m}$ east of the Structure with Bone, in B12.

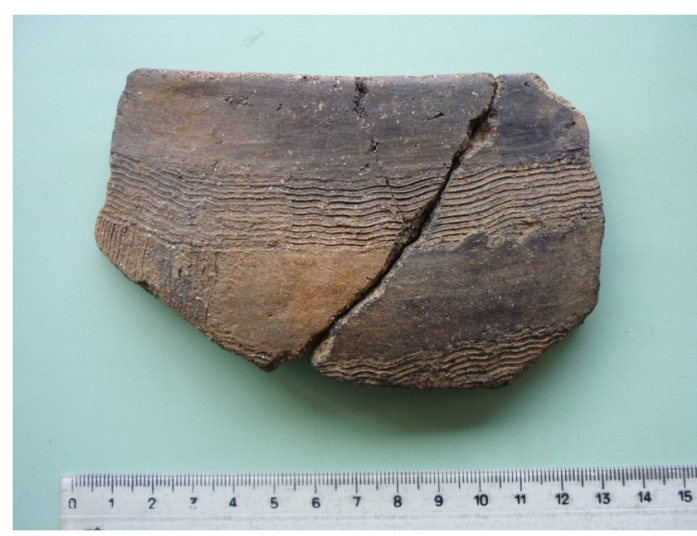

Fig. 21. Refits between sherd (31) from the Structure with Bone and sherd (2028) from quadrant H11.

Fig. 21. Colagem entre o fragmento 31 da Estrutura com Ossos Humanos e o fragmento 2018 da quadrícula H11.

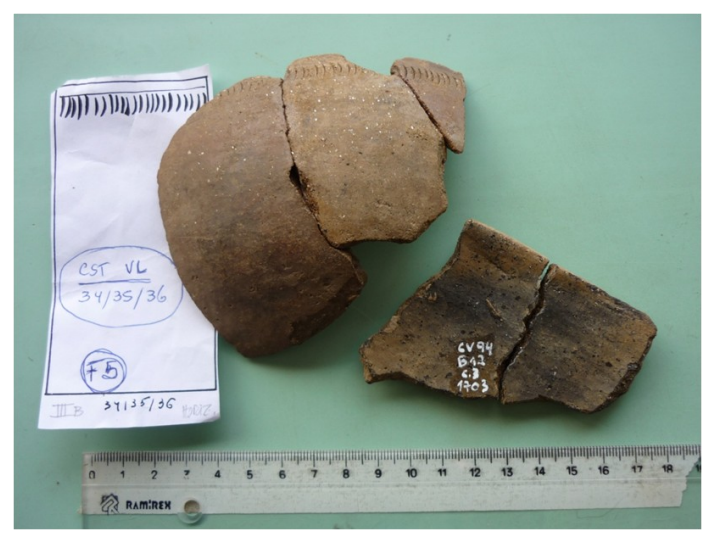

Fig. 22. Refits between sherds $(34,35,36)$ from the Structure with Bone and sherd (1703) from B12.

Fig. 22. Colagem entre os fragmentos 34,35 e 36 da Estrutura com Ossos Humanos e o fragmento 1703 da quadrícula B12.

In summary, I did not find any refitting pieces of pottery between the area Under the Ramp, the Ramp, and the Structure with Bone, but instead evidence for refits from the Structure with Bone operated at a larger scale across the site. This is similar to the findings of Baptista who, in her analysis of refits and their spatial distribution by quadrant, also discovered 12 refits that were across quadrants and which are further evidence for dynamics that operated across the site at a larger scale than that of the archaeological feature (BAPTISTA 2003: 130, Plan 24).

\section{CONCLUSIONS}

I hope this paper demonstrates the importance of post-breakage histories in material culture studies, and how these change the interpretation of contexts when they are directly connected to histories of architecture. By bringing entire pottery assemblages into focus and exploring their individual components in detail, we can move towards a more sensitive consideration of depositional practices. By appreciating the fact that ceramic deposits are 
comprised of material with different pre and postbreakage histories, it is possible to unpick the processes that underpinned this practice (both mundane and otherwise), and to be released from the simplistic and selective approach of seeking out the 'special'. This work is a new strand of thinking on the nature of the relationship between in situ artefactual material and the archaeological feature, and it identifies and highlights missing contexts. In addition, this analysis offers a new interpretation on the temporality of practice in the Chalcolithic.

\section{Occupation as architecture}

It is not simply the case that the study of material culture needs to be drawn into our understandings of the architectural history of a site; rather an analysis of the patterns of fragmentation of pottery demonstrate that occupation is a part of the architectural process itself. Traditionally, in our archaeological accounts, we associate the study of pottery with our interpretations of the occupation of a site, and then the details of the physical and spatial location of the pottery are used to interpret deposition in architecture. Even if I stay with these traditional terms to interpretation, with the Two Hearth and Ramp contexts there were no indications of other activities that separated occupation and architecture; instead the signature of the pattern of fragmentation, and the nature of the breaks on the sherds, argue for the bringing together of these actions. There is a more direct temporal trajectory between the breakage of pots and the deposition of sherds for these two contexts. My analysis highlights the specificity of the temporal conditions of each of these groups of sherds, and indicates that there is an imperative relationship between occupation and architecture. For example, the less fragmentary nature of the sherds (many from fine wares), and that the vessels were represented by several sherds, that were associated with the Two Hearths indicates a connection in time with the closure of the entrance and the elaboration of the enclosure wall. From within the matrix of the Ramp there were also a surprising number of fresh, homogenous, refitting, medium sized pieces of pottery. These patterns do not illustrate a direct trajectory from the breaking of a pot to its incorporation into architectural practice (for there was no evidence for whole pots in any of the contexts that I looked at), but they do demonstrate the need to integrate these practices more closely than we have been doing.

Contrarily, where previously we have associated material culture and architecture more closely together in our accounts of deposition, be it the idea that parts of pots are arranged in concentrations in the Pit, or that parts of pots and seeds are deposited together in the Structure with Seeds, or that sherds were in notable concentrations around a structure that was 'clean' of artefacts in Area 6. In these cases, the patterns of fragmentation indicate addi- tional activities between the breaking of pots and the deposition of sherds; and they indicate an elsewhere, an other space where the material existed prior to the feature. Furthermore, these additional activities, when considered as actions in time, have different temporal trajectories i.e. there is an extended temporality to the accumulation of material pre-Pit and pre-Area 6 , than there was with the sherds caught up with fire activity pre-Structure with Seeds. In doing this, we have to start thinking about what it means when people arrange material rather than objects, for the four concentrations of mixed sherds in the Pit would no longer have been recognizable as being from particular pots, and similarly the sherds in Area 6 had accumulated elsewhere before they were deposited near to the structure. With the Structure with Seeds, it does not demean the importance of this arrangement of sherds and seeds if we have to think about the histories of particular broken pots and how these were caught up in more everyday practices that involved seed histories, prior to deposition. Therefore we need to add to our stories, add other practices: there was the accumulation of broken pots, with some of the sherds having been caught up in burning practices (perhaps along with charred seeds), before the deposition of these things in the structure. And we must not forget that here the larger sherds, along with pieces of stone, were used to cap the Structure with Seeds. This process of sherds and stone, being used as constructional materials together, was also seen in the closure of the entranceway of the wall with the Two Hearth context, and in the capping of the Structure with Bone. Perhaps we need to think in a different way about occupation, rather than thinking of it as an activity that comes after architecture, practices of occupation can instead project forward and create the conditions for architecture: practices of occupation involve histories of pottery and are what give architecture its rhythm and tempo.

\section{Domestic as ritual}

The study of prehistory has been characterised by an almost bi-polar disorder of 'domestic' or 'ritual' interpretations of the evidence, or put more positively, by how best to relate these two aspects of interpretative practice. As regards the Structure with Bone at Castelo Velho, an important approach has been to describe the nature of all of the material culture that was recovered with the parts of the human bodies, and the way in which these things were associated together on spatial terms within 'moments' of deposition (S.O. JORGE et al. 19981999). António Valera has also written about the importance of this approach: '...os fragmentos de materiais são tratados, não como resíduos descartados, mas como elementos activamente participantes nas actividades rituais' (2010: 37, the fragments of materials are treated not as discarded waste but as elements actively participating in ritual activities). 
It is so important that Valera has remarked on the line that has been taken to the Structure with Bone, and he is correct in pointing out that all the elements from this context are active participants, but this participation was not frozen in time to the space of the deposit. Let me explain. In his article, Valera picks up on the two types of fragmentation that were distinguished within the Structure with Bone in the previous published account: the articulated parts of the human body, the small and near intact vessel, and the intact or near intact loomweights; and then the disarticulated human bone, the animal bones, the sherds of pottery, and the pieces of loomweights (S. JORGE et al. 1998-1999: 46; VALERA 2010: 37). As much as I admire this work, it misses out the crucial point that the sherds of pottery are evidence for more than the beginning and end of a sequence in the biography of an object (i.e. of pot and sherd). Studies of fragmentation account for a bigger temporal and spatial trajectory, that is not fixed in the spatial framing and moment of the structure: sherds hold with them histories that extend from pre-breakage out to the post-breakage activities that the pottery was caught up in. Differences in practice are indicated by sherd histories: i.e. we cannot jump from a discussion of differences in types of ceramic to differences in kinds of fragment; our discussion needs to be about differences in practice. Crucially not all of these actions are sealed within the structure, or parcelled up in the account of deposition, they occurred before deposition and in other spaces.

If you take the entire pottery assemblage of the Structure with Bone into focus, the signature of the fragmentation is of a great percentage of medium-sized sherds over a large proportion of small sherds, and then very few large sherds at all (see Fig. 11). Of the medium-sized pieces they were predominantly plain body sherds with multiple refits. Therefore the majority of the sherds that were recovered from the Structure with Bone is not accounted for in Valera's interpretation, they lie inbetween the two kinds of fragmentation that he identified. The pieces that make up the majority of the assemblage do not stand out, perhaps precisely because they are plain and medium, if you like they are the 'infra-ordinary' (after Georges Perec). Yet, it is their everyday nature that is so important and that needs attending to. I state again, that it is important to consider the fact that it is occupation that gives architecture its rhythm and tempo at Castelo Velho. Furthermore, the overall signature of the pattern of fragmentation in the Structure with Bone is the same as that of the Two Hearths and the Structure with Seeds. The nature of the pottery assemblage (especially concerning the number of refitting pieces), the nature of the breaks (in particular the fresh nature of many of the breaks), and the overall pattern of the fragmentation indicate a shorter period of time between the breaking of vessels and the deposition of sherds. However, this is where the large proportion of medium sized pieces, and the non-complete nature of the vessels, really comes into play because there was not evidence for a direct connection between breakage and deposition, there is a crucial absence of large sized pieces and nearcomplete refits. Similarly there were a large number of small sherds with weathered and abraded edges that are a part of the assemblage and that are evidence for other practices post-breakage and predeposition. Rather than concentrating on the meaning of placing unbroken or broken objects in a deposit that is for the dead, instead we should concentrate on the temporality of practice that is involved. People were living in and around broken things before they entered this structure, prior to deposition, and it is that occupation, the daily practice of living with things (many in a broken state), that creates the conditions for a Structure with Bone. Maybe it is precisely because activities were produced out of occupation that the Structure with Bone was constructed as a part-open part-closed feature, and that this is why we have refitting pieces of pottery that exist at the larger scale of the site. This is not to deny the ritual aspects of the feature, but instead argue for a close examination of the everyday to the extent that it is rendered unfamiliar.

'The daily newspapers talk of everything except the daily. The papers annoy me, they teach me nothing. What they recount doesn't concern me, doesn't ask me questions and doesn't answer the questions I ask or would like to ask. What's really going on, what we're experiencing, the rest, all the rest, where is it? How should we take account of, question, describe what happens every day and recurs everyday: the banal, the quotidian, the obvious, the common, the ordinary, the infra-ordinary, the background noise, the habitual?' (PEREC, 'L' Infraordinaire' 1989 (2008): 209).

\section{ACKNOWLEDGEMENTS}

This research was carried out between April 2009 and August 2011 at the University of Porto on a post-doctoral fellowship. The fellowship was supervised by Susana Oliveira Jorge and funded by the Fundação para a Ciência e a Tecnologia, and I am grateful to them both. Thank you to Susana Oliveira Jorge and Maria de Lurdes Oliveira for permission to reproduce fragments of the drawn and photographic archive of Castelo Velho.

Thank you to Sergio Gomes, Mark Knight and Ana Vale for their help developing the ideas presented here, and for reading and commenting on the text. The article has also benefitted from the comments of two reviewers.

\section{REFERENCES}

BAPTISTA, L. 2003. A cerâmica do interior do recinto de Castelo Velho. Contributos para a interpretação dos contextos de uso. Porto, FLUP (dissertação de mestrado policopiada).

Baptista, L; Gomes, S; Jorge, S.O; Jorge, V.O; MurALHA, J; OliVeira, L; Pereira, L; VAle, A; Velho, G. \& VIEIRA, A. 2006. Uma história de dois vizi- 
nhos ao longo de 17 anos: Castelo Velho e Castanheiro do Vento (1989-2006). Pré-história gestos intemporais. III Congresso de Arqueologia Trás-osMontes, Alto Douro e Beira Interior: Vila Nova de Foz Côa: 120-135.

Botelho, I. 1996. Dos cacos e dos vasos. O Castelo Velho de Freixo de Numão na charneira do $I I I^{\circ} / I^{\circ}$ Milénio A.C. Contributos para o estudo da cerâmica pré -histórica de Castelo Velho. Porto, FLUP (dissertação de mestrado policopiada).

Brudenell, M. \& COOPER. A. 2008. Post-Middenism: Depositional Histories on Later Bronze Age Settlements at Broom, Bedfordshire. Oxford Journal of Archaeology 27(1): 15-36.

CARdoso, J. Muralha 1996. Materiais Liticos e Cerâmicos de Castelo Velho de Freixo de Numão. Continuidades e Descontinuidades: uma propostas de abordagem estatística. Porto, FLUP (dissertação de mestrado policopiada).

CruZ, M. D. 1993. Significado Social da Cerâmica Doméstica. Fundamentos para uma classificação tipológica da cerâmica de castelo Velho (Freixo de Numão - V.N. de Foz Côa). Porto, FLUP (dissertação de mestrado policopiada).

Evans, R. 1996. Translations from Drawing to Building and Other Essays. London, Architectural Association Publications.

Garrow, D; Beadsmoore, E. \& KNIGHT, M. 2005. Pit Clusters and the Temporality of Occupation: an Earlier Neolithic Site at Kilverstone, Thetford, Norfolk. Proceedings of the Prehistoric Society 71: 139-157.

Gomes, S. R. 2003. Contributos para o estudo dos "pesos de tear" de Castelo Velho de Freixo Numão. Exercícios de interpretação do registo arqueológico, Porto, FLUP (dissertação de mestrado policopiada).

HiLl, J. (ed.) 1998. Occupying Architecture: Between the Architect and the User. London, Routledge.

HILL, J. 2003. Actions of architecture: architects and creative users. London, Routledge.

JoRGE, S.O. 1994. Colónias, fortificações, lugares monumentalizados, trajectós das concepções sobre um tema do Calcolítico peninsular. Revista da Faculdade de Letras, $2^{\mathrm{a}}$ série. XI: 447-546.

JorGE, S.O. 1999. Revisiting some earlier papers on the late prehistoric walled enclosures of the Iberian Peninsula. Journal of Iberian Archaeology. 5: 89-135.

JoRGE, S.O. 2003. Pensar o espaço da pré-história recente: a propósito dos recintos murados da Península Ibérica. In JoRge, S.O. (coord.) Recintos Murados da Pré-História Recente, Porto/Coimbra, DCTP (FLUP)/CEAUCP (FCT): 13-50.
Jorge, S.O. 2005. O Passado é Redondo. Dialogando com os sentidos dos primeiros recintos monumentais. Porto, Edições Afrontamento.

JORGE, S.O. 2007. Formas de organização do espaço e técnicas de construção durante a pré-história recente. In Jorge, S.O; BetTenCOURT, A.M.S. and FigueIRAL, I. (eds.) A concepção das paisagens e dos espaços na Arqueologia da Península Ibérica, Promontoria Monográfica 08, Universidade do Algarve: 9-12

Jorge, S.O; OliveirA, M.L; Nunes, S.A. \& GOMES, S.R. 1998/99. Uma estrutura ritual com ossos humanos no sítio pré-histórico de Castelo Velho de Freixo de Numão (V.N. de Foz Côa). Portugalia, Nova Série. XIX-XX: 29-70.

Jorge, S.O; BAPTISTA, L; GOMes, S; Oliveira, L; VARElA, J.M. \& VELHO, G. 2007. A construção de um sítio arqueológico: Castelo Velho de Freixo de Numão. In Jorge, S.O; Bettencourt, A.M.S. and FigueIRAL, I. (eds.) A concepção das paisagens e dos espaços na Arqueologia da Península Ibérica. Promontoria Monográfica 08, Universidade do Algarve: 77-86

OLIVEIRA, M.L. 2003. As primeiras intervenções arquitectónicas no Castelo Velho de Freixo Numão. Porto, FLUP (dissertação de mestrado policopiada).

PEREC, G. 1989 (translation 2008). L'Infra-ordinaire. In Species of Spaces and Other Pieces. London, Penguin Classics: 207-249

PEREIRA, L.R.F.S., 1999. As Cerâmicas de "Cogeces" de Castelo Velho, Freixo de Numâo (Vila Nova de Foz Côa). Seu Enquadramento Peninsular, Porto, FLUP (dissertação de mestrado policopiada).

PINNEY, C. 2005. Things Happen: Or, From Which Moment Does That Object Come? In Miller, D. (ed.) Materiality. Durham. N.C., Duke University Press.

Silva, C. 1996. O Povoado Pré-Histórico de Castelo Velho de Freixo de Numão no Quadro do Povoamento da $2^{a}$ Metade do $I I I^{o}$ Milénio A.C $/ 1^{a}$ Metade do $I^{o}$ Milénio A.C. no concelho de V.N. de Foz Côa”). Porto, FLUP (dissertação de mestrado policopiada).

VALERA, A.C. 2010. Marfim no recinto Calcolítico dos Perdigões (1): 'lúnulas', fragmentação e ontologia dos artefactos. Apontamentos de Arqueologia e Património. 5: 31-42.

VARELA, J.M. 2000. As cerâmicas do Bronze Inicial e Médio do Castelo Velho de Freixo de Numão (V.N. Foz Côa). Tradição e Inovação na transição do $I I^{\circ}$ para o II Milénio A.C. Porto, FLUP (dissertação de mestrado policopiada). 